\title{
Mesenchymal Stromal Cells for the Treatment of Interstitial Lung Disease in Children: A Look from Pediatric and Pediatric Surgeon Viewpoints
}

\author{
Gloria Pelizzo ${ }^{1,2, *}$, Serena Silvestro ${ }^{3}$, Maria Antonietta Avanzini $\left.{ }^{4}{ }^{(}\right)$, Gianvincenzo Zuccotti ${ }^{2,5}{ }^{(0)}$, \\ Emanuela Mazzon ${ }^{3,+}$ and Valeria Calcaterra $5,6,+(\mathbb{D}$ \\ 1 Pediatric Surgery Department, Children's Hospital “Vittore Buzzi”, 20154 Milano, Italy \\ 2 Department of Biomedical and Clinical Sciences-L. Sacco, University of Milan, 20157 Milan, Italy; \\ gianvincenzo.zuccotti@unimi.it \\ 3 IRCCS Centro Neurolesi "Bonino-Pulejo", Via Provinciale Palermo, Contrada Casazza, 98124 Messina, Italy; \\ serena.silvestro@irccsme.it (S.S.); emanuela.mazzon@irccsme.it (E.M.) \\ 4 Cell Factory, Pediatric Hematology Oncology Unit, Fondazione IRCCS Policlinico San Matteo, \\ 27100 Pavia, Italy; ma.avanzini@smatteo.pv.it \\ 5 Department of Pediatrics, Children's Hospital “Vittore Buzzi”, 20154 Milano, Italy; valeria.calcaterra@unipv.it \\ 6 Pediatrics and Adolescentology Unit, Department of Internal Medicine, University of Pavia, 27100 Pavia, Italy \\ * Correspondence: gloriapelizzo@gmail.com \\ + These authors contributed equally to this work.
}

check for updates

Citation: Pelizzo, G.; Silvestro, S.; Avanzini, M.A.; Zuccotti, G.; Mazzon,

E.; Calcaterra, V. Mesenchymal

Stromal Cells for the Treatment of Interstitial Lung Disease in Children: A Look from Pediatric and Pediatric Surgeon Viewpoints. Cells 2021, 10, 3270. https://doi.org/10.3390/ cells10123270

Academic Editor: Joni H. Ylostalo

Received: 11 October 2021

Accepted: 21 November 2021

Published: 23 November 2021

Publisher's Note: MDPI stays neutral with regard to jurisdictional claims in published maps and institutional affiliations.

Copyright: (c) 2021 by the authors. Licensee MDPI, Basel, Switzerland. This article is an open access article distributed under the terms and conditions of the Creative Commons Attribution (CC BY) license (https:// creativecommons.org/licenses/by/ $4.0 /)$.

\begin{abstract}
Mesenchymal stromal cells (MSCs) have been proposed as a potential therapy to treat congenital and acquired lung diseases. Due to their tissue-regenerative, anti-fibrotic, and immunomodulatory properties, MSCs combined with other therapy or alone could be considered as a new approach for repair and regeneration of the lung during disease progression and/or after post- surgical injury. Children interstitial lung disease (chILD) represent highly heterogeneous rare respiratory diseases, with a wild range of age of onset and disease expression. The chILD is characterized by inflammatory and fibrotic changes of the pulmonary parenchyma, leading to gas exchange impairment and chronic respiratory failure associated with high morbidity and mortality. The therapeutic strategy is mainly based on the use of corticosteroids, hydroxychloroquine, azithromycin, and supportive care; however, the efficacy is variable, and their long-term use is associated with severe toxicity. The role of MSCs as treatment has been proposed in clinical and pre-clinical studies. In this narrative review, we report on the currently available on MSCs treatment as therapeutical strategy in chILD. The progress into the therapy of respiratory disease in children is mandatory to ameliorate the prognosis and to prevent the progression in adult age. Cell therapy may be a future therapy from both a pediatric and pediatric surgeon's point of view.
\end{abstract}

Keywords: mesenchymal stromal cells; children; interstitial lung disease; pediatrics

\section{Introduction}

Stem cell therapy represents a prospective approach in regenerative medicine for the repair, replacement, and rejuvenation of tissue [1,2]. Mesenchymal stromal cells (MSCs) expanded in vitro have been proposed as potential therapy to treat congenital and acquired lung diseases [2-11]. MSCs are multipotent cells that can differentiate into multiple tissue-forming cell lineages, such as osteoblasts, adipocytes, chondrocytes, tenocytes, and myocytes. In addition, MSCs regulate immune and inflammatory responses. MSCs are characterized by an innate self-renewal capacity, and they can be in vitro expanded without losing their differentiation potential [12].

The lung originates from the endodermal and mesodermal germline. Each phase in lung development is reliant on inductive cues and reciprocal interactions between the pulmonary epithelium and the surrounding mesenchyme. Loss of or abnormalities in 
cells and in their interactions can lead to severe anatomical and functional defects in the airway and alveoli [13-16]. MSCs are key cells in the connective pulmonary tissue hierarchy, supporting the crucial relationship between the epithelium and mesenchyme during branching morphogenesis [13-16].

Interstitial lung disease in children (chILD) is a group of highly heterogeneous and rare respiratory diseases with wide ranges in the age of onset and disease expression [2,17-19]. chILD is characterized by inflammatory and fibrotic changes in the pulmonary parenchyma, leading to gas exchange impairment and chronic respiratory failure associated with high morbidity and mortality. chILD disorders often overlap, and the classifications remain difficult. chILD is characterized by abnormality of the lung interstitium, alveoli, and distal air spaces, leading to chronic respiratory failure. Even though chILD pathogenesis remains unclear, the aberrant activation of the alveolar epithelium and mesenchyme has been proposed as a crucial player [18,20]. A multidisciplinary approach to the diagnosis and follow-up is mandatory to provide improved care. Surgery may represent a critical step for management. The therapeutic strategy is mainly based on the use of corticosteroids, hydroxychloroquine, azithromycin, and supportive care; however, the efficacy is of these methods is variable. The role of MSCs as a state-of-the-art treatment has been proposed in clinical and preclinical studies [4,21-29].

This narrative review reports the information currently available on MSCs treatment as a new therapeutic strategy in chILD. To evaluate the efficacy of MSCs treatment, the pre-clinical and clinical results on bronchopulmonary dysplasia (BDP) were also included as model of chronic respiratory diseases characterized by interstitial lung abnormalities leading to chronic failure. The need for research to advance the therapy of pulmonary diseases is mandatory to improve the prognosis and to prevent their progression in adulthood. Cell therapy, as reparative and regenerative treatment, may be innovative from both the pediatric and pediatric surgeon's viewpoint.

\section{Methods}

A narrative review of the English literature published in the past 10 years was conducted. We independently identified the most relevant published manuscripts including original papers, metanalyses, clinical trials, and reviews. Case reports or series and letters were excluded. Human and experimental studies were included. Papers were searched using the following keywords in combination: "children interstitial lung disease and mesenchymal stromal cells", "children idiopathic pulmonary fibrosis and mesenchymal stromal cells" and "infants bronchopulmonary dysplasia and mesenchymal stromal cells and clinical trials". The following electronic databases were searched: PubMed, Scopus, EMBASE, and Web of Science. In this study, we included clinical studies recorded on ClinicalTrial.gov searched with the following keywords in combination: "stem cells" and "infants bronchopulmonary dysplasia". The contributions were critically reviewed and collected. The final version was approved by all authors.

\section{Mesenchymal Stromal Cells and MSCs-Derived Extracellular Vesicles}

Cell therapy has recently received considerable interest as a treatment of respiratory system diseases. Several lines of evidence encourage the use of MSCs in lung diseases [30,31]. The ease of isolation, the lack of immunogenicity, and the ability to expand ex vivo and to differentiate in multilineages make MSCs an attractive therapeutic tool. The therapeutic potential of MSCs is due to their paracrine effect, supported by their secretion of extracellular vesicles (EVs), transferring genetic material, and releasing of soluble factors such as cytokines. The conditioned medium (CM) or secretome is defined as the products secreted by MSCs in their cultured medium [32-34]. In Vivo administration of MSCs, as well as of their products, appears a suitable approach for injured lung tissue repair by reducing fibrosis and stimulating proper alveolar and vascular repair $[35,36]$. 


\subsection{Mesenchymal Stromal Cells (MSCs)}

MSCs are a population of multipotent nonhematopoietic stromal cells, capable of differentiating into tissue derived from the three main mesodermal lineages. MSCs represent a cell population with secretion [37], homing [38], and immunomodulatory [39] properties.

MSCs can be isolated from various sources, including bone marrow, adipose tissue, skeletal muscle, synovium, spleen, thymus, lung, and amniotic fluid. The International Society for Cell and Gene Therapy reported, as minimal criteria for their definition: plastic adherence when in vitro cultured; the expression of surface markers such as CD105, CD73, and CD90; and the absence of the expression of endothelial and hematopoietic markers such as CD11b, CD14, CD19, CD34, CD45, CD79a, and class II human leukocyte antigenDR (HLA-DR) [40,41]. They have to show the capability to differentiate in vitro into tissues of mesodermal origin, such as osteoblasts, adipocytes, and chondroblasts. Subsequently, it was shown that MSCs can transdifferentiate into neural cells, pancreatic cells, liver cells, and cardiomyocytes [42].

MSCs can exert several functions including immunomodulatory effects through inhibition of T-cell proliferation and secretion of anti-inflammatory cytokines and growth factors $[43,44]$. In Vivo, their effects were reported to be mediated by paracrine mechanism with the release of growth factors, which stimulate endogenous repair pathways [12] and host inflammation sites that express anti-inflammatory cytokines to dampen the host's immune response [45].

It is a long-established fact that MSCs infuse intravenously; while circulating within the lungs, they remain partially entrapped, producing the pulmonary first-pass effect. This effect represents one of the hurdles faced by MSCs therapy when targeting other organs, but may be an inherent advantage when biotherapy with MSCs is directed to the lungs. The ability to deliver MSCs to the lungs via a simple intravenous approach has the potential for large-scale retention [11,46,47]. Even more attractively, retained cells appear to target areas of injured lung where they differentiate into specific cell types and start regeneration [48]. Both in vitro and In Vivo, MSCs have been observed to differentiate into alveolar epithelial cells, indicating their potential as a regenerative therapy for lung diseases [49-51].

Isolation and culture make MSCs suitable candidates for preclinical and clinical studies. Effectively, clinical trials phase I in patients with chronic obstructive pulmonary disease (COPD) confirmed the safety of MSCs; outcomes from phase I/II clinical trial administration and investigation showed their potential anti-inflammatory effects, reporting a reduction in C-reactive protein levels [52].

\subsection{Extracellular Vesicles (EVs)}

MSCs also exert their therapeutic effects through the release of EVs. MSCs-derived EVs are small membrane-bound vesicles that contain biomolecules including proteins, lipids, microRNA, and mRNA, which play a role as mediators in cellular communication to maintain physiological homeostasis [53].

EVs provide intercellular communication by transferring their membrane contents to the target cells through the binding of surface receptors $[54,55]$. EVs, according to their origin, are divided into microvesicles and exosomes [56]. Microvesicles are generated by direct budding of the plasma membrane toward the extracellular environment through a calcium-induced asymmetric reorganization of phospholipids [57]. Membrane germination is induced by calpain and gelsolin, proteases that cut the protein network of the cytoskeleton [58]. The exosomes instead originate from the intracellular fusion of the endosomes with the endocytic vesicles, thus incorporating their contents. After maturation, endosomes merge with the plasma membrane, becoming exosomes that are released into the extracellular space [59]. The microvesicles are larger, ranging from 50 to $1000 \mathrm{~nm}$; exosomes are smaller, with a size ranging from 40 to $120 \mathrm{~nm}[60,61]$. Western blot and mass spectrometry analyses allowed the identification of proteins expressed in EVs [60,61]. In particular, microvesicles contain phosphatidylserine, metalloproteinases, some integrins, and P-selectin [62]. Exosomes contain proteins with GTPase activity involved in transport 
and fusion [63], heat shock proteins (Hsp 60, Hsp70, Hsp90) [59,63], and tetraspanins (CD63, CD81, and CD9), which are necessary in the fusion between exosomes and recipient cells [64]. EVs' composition and structure are different according to the mother cell. Moreover, EVs mediate horizontal mRNA transfer to a recipient cell $[59,65]$. As such, EVs are able to change the phenotype and function of the recipient cells, regulating different cellular pathways and activating regenerative mechanisms. Therefore, MSC-derived EVs could be capable of restoring the homeostasis of damaged tissues [66] and interacting with immune system cells [67], demonstrating regenerative and anti-inflammatory properties [68]. The use of EVs confers some advantages compared to the use of original stem cells, such as a higher safety profile, an increased ability to cross biological barriers, lower immunogenicity, and poor immune rejection. Despite the advantages shown by MSC-derived EVs, their use in clinical studies requires further investigation to resolve critical issues related to the methods of production, characterization, quantification, pharmacokinetics, and transfer to target sites [69].

\subsection{Conditioned Medium (CM)}

The CM/secretome from cultured MSCs, containing both soluble factors and EVs, may represent a significant tool to produce efficacy similar to the original cells [70]. A systematic review and meta-analysis of preclinical studies, including different lung diseases such as bronchopulmonary dysplasia, asthma, pulmonary hypertension, acute respiratory distress syndrome, chronic obstructive pulmonary disease, and pulmonary fibrosis, recorded comparable efficacy between CM and MSCs [71]. To obtain CM from cultured MSCs, different collection timings, confluence grades, and culture passages have been reported in the literature [72-74]. As already underlined, MSC-derived CM consists of all MSCsecreted cytokines, proteins, growth factors, and EVs [75]; it contains several angiogenic growth factors, such as vascular endothelial growth factor (VEGF) [76,77]. In in vitro models, it was shown that MSC-derived CM containing high levels of VEGF promoted angiogenesis and the regeneration of periodontal tissue [78]. In another study, the addition of anti-VEGF antibodies to MSC-derived CM decreased vessel formation and induced poor bone regeneration in a rat calvaria model [77].

In line with these findings, in a mouse model of Escherichia coli endotoxin-induced model of acute lung injury (ALI), administration of MSC-derived CM induced a reduction in septal thickening, alveolar hemorrhage, alveolar infiltrates, and fibrin filaments compared to untreated mice. Similar reductions in neutrophils and lung permeability were observed both after treatment with MSCs or CM [79]. Moreover, in a rat model of bleomycin-induced pulmonary fibrosis, administration of MSC-derived CM reduced the deposition of collagen involved in fibrosis [80].

Therefore, these data encourage the use of the $\mathrm{CM}$ as potential cell-free therapy; however, it is necessary to identify and standardize the most advantageous cellular source, the culture method, and the purification method to obtain the maximum therapeutic yield.

\section{Routes of Administration of MSCs}

The use of MSCs as treatment for respiratory diseases, although promising, needs to overcome some limitations. Some of these include determining the optimal dosage, the cell type, and the appropriate route of administration.

In preclinical and clinical studies, cell therapy envisages systemic administration, such as intravenous or intra-arterial infusion or local administration via intratracheal administration [81]. Intravenous cell infusion causes the accumulation of MSCs in the lungs, an effect known as the first pass [82]. This phenomenon may represent an obstacle when MSCs therapy is aimed toward other organs but may be a notable advantage when MSC therapy is directed to the lungs. However, it has been shown that this entrapment is transient, followed by a distribution of the cells to other organs, such as the spleen and liver, during the following 24-48 $\mathrm{h}$ [83-85]. 
In an In Vivo study performed in a rodent silicosis model with intravenously administered bone-marrow-derived MSCs (BM-MSCs), the first pass event was observed six hours after treatment [86], whereas in a rodent model of myocardial infarction, it occurred within minutes with subsequent embolization [87]. However, the small diameter of the pulmonary microcirculation and the presence of adhesion receptors may prevent MSCs from reaching the targeted lung site [88]. MSCs entrapment in the vascular system can induce the formation of an embolus, as demonstrated by a clinical study in which cell therapy promoted venous thrombosis in two patients with Crohn's disease [89]. Instead, intra-arterial infusion allows reaching the target organ, avoiding entrapment inside the lung $[81,82,90]$. However, even this procedure may be harmful due to the possible generation of emboli in microcirculation [91].

The local administration has greater or equal therapeutic potential at lower dosages than systemic administration [92]. For cell therapy, local delivery to the lungs occurs by intratracheal administration [81]. This route, although a possible cause of trauma and injury, has been reported to produce promising therapeutic outcomes in several clinical studies [36,93,94], showing MSCs engraftment into the lung in real time [88]. However, the available data are contradictory and insufficient to identify the most suitable route for MSC infusions both in terms of safety and of targeted delivery to a specific area of the organ, in particular in the lung.

\section{Interstitial Lung Disease in Children (chILD)}

chILD refers to a heterogeneous group of rare lung disorders, with a wide range of prevalence (from 0.13 to $16.2 / 100,000$ children/year) as a result of a lack of standardized diagnostic criteria, and a heterogeneous clinical presentation and pathological picture $[17,18]$. chILD is characterized by abnormalities in the lung interstitium, alveoli, and distal air spaces, leading to abnormal gas exchange and chronic failure $[17,18]$.

The pathogenesis of chILD is complex and has not yet been fully elucidated. The central role of the alveolar epithelium and aberrant mesenchymal activation has been proposed $[18,20]$. The involvement of repeated injuries of vulnerable alveolar epithelial cells (AECs) and the failure of the alveoli to respond to injury, leading to aberrant lung repair and progressive fibrosis, were suggested to be involved in pathogenesis [95]. An acceleration of the ageing process of progenitor cells, leading to stem cell exhaustion, was also proposed [96]. The initial recruitment of inflammatory cells including collagenproducing fibrocytes is not excluded in the pathophysiology of alveolar injury.

chILD comprises more than 200 different conditions, for which different classification systems have been proposed based on the etiology and physiopathology and lung biopsies $[18,20]$. As reported in Table 1 , more recently, a subclassification considering infancy ILD different from other pediatric ILD was introduced, again on the basis of etiologic and pathologic criteria $[17,18,97-99]$.

In most of the chILD cases, no family history is documented; moreover, the occurrence of familial forms with an estimated prevalence ranging from 1.3 to 5.9 per million has been reported $[17,18]$. Mutations in the surfactant protein (SP) genes, mainly in SP-B and -C genes, are responsible for the familial form $[17,18]$. As reported in Table 2, other genetic forms have been described. 
Table 1. Classification of children's interstitial lung disease according to Rice et al. [97].

\begin{tabular}{|c|c|}
\hline Disorders More Prevalent in Infants & Disorders More Prevalent in Children \\
\hline $\begin{array}{l}\text { Diffuse developmental disorders (acinar dysplasia, alveolar } \\
\text { capillary dysplasia, congenital alveolar dysplasia) }\end{array}$ & $\begin{array}{l}\text { Disorders related to systemic disease (Langerhans cell } \\
\text { histiocytosis, related to acquired heart disease, storage } \\
\text { disease/endogenous lipid pneumonia) }\end{array}$ \\
\hline $\begin{array}{c}\text { Growth abnormalities (alveolar hypoplasia, chronic neonatal } \\
\text { lung disease, related to chromosomal disorders, related to } \\
\text { congenital heart disease) }\end{array}$ & $\begin{array}{l}\text { Disorders of the normal host (eosinophilic } \\
\text { bronchiolitis/pneumoniae, infection/post infectious processes, } \\
\text { hypersensitivity pneumonitis, aspiration pneumonia) }\end{array}$ \\
\hline $\begin{array}{l}\text { Specific conditions of undefined etiology (neuroendocrine cell } \\
\text { hyperplasia of infancy, pulmonary interstitial glycogenosis) }\end{array}$ & $\begin{array}{l}\text { Disorders of the immunocompromised host: } \\
\text { (opportunistic infection, transplant-related) }\end{array}$ \\
\hline \multirow[t]{5}{*}{ Surfactant protein disorders } & $\begin{array}{l}\text { Disorders masquerading as ILD (pulmonary hypertension, } \\
\text { veno-occlusive disease, lymphatic disorders capillary } \\
\text { hemangiomatosis, thromboembolic disease, vasculitis) }\end{array}$ \\
\hline & $\begin{array}{l}\text { Lymphoproliferative disease (lymphoid interstitial pneumonia, } \\
\text { diffuse lymphoid hyperplasia, lymphomatoid granulomatosis) }\end{array}$ \\
\hline & $\begin{array}{l}\text { Small airways disease (chronic bronchiolitis, obliterative } \\
\text { bronchiolitis, follicular bronchiolitis) }\end{array}$ \\
\hline & $\begin{array}{l}\text { Interstitial pneumonias unrelated to surfactant protein disorder } \\
\text { (organizing pneumonia, diffuse alveolar damage, usual } \\
\text { interstitial pneumonia) }\end{array}$ \\
\hline & $\begin{array}{l}\text { Other patterns of diffuse lung disease (hemosiderosis, alveolar } \\
\text { microlithiasis, sarcoidosis) }\end{array}$ \\
\hline
\end{tabular}

Table 2. Genetic mutations associated with children's interstitial lung disease.

\begin{tabular}{|c|c|c|}
\hline Genetic Mutation & Inheritance & Lung Involvement \\
\hline SFTPB (surfactant protein B deficiency) & Autosomal recessive & Surfactant disorder \\
\hline SFTPC (surfactant protein C mutation) & Autosomal dominant & Surfactant disorder \\
\hline $\begin{array}{c}\text { CSF2RB (colony stimulating factor } 2 \\
\text { receptor } \beta \text { ) }\end{array}$ & Autosomal recessive & Pulmonary alveolar proteinosis \\
\hline CSF2RA (colony stimulating factor 2 receptor $\alpha$ ) & X-linked & Pulmonary alveolar proteinosis \\
\hline ABCA3 (ATP-binding cassette-family A-member 3) & Autosomal recessive & Deficit surfactant \\
\hline COPA (coatomer associated protein subunit alpha) & Autosomal dominant & General disorder including lung \\
\hline FLNA (Filamin A) & X-linked recessive & General disorder including lung \\
\hline FOXF1 (forkhead box F1) & Autosomal dominant & Alveolar capillary dysplasia \\
\hline GATA2 (GATA Binding Protein 2) & Autosomal dominant & Pulmonary alveolar proteinosis \\
\hline MARS (metionil-transfer RNA sintetasi) & Autosomal recessive & Pulmonary alveolar proteinosis \\
\hline NKX2-1 (NK2 homeobox 1) & Autosomal dominant & Interstitial lung disease \\
\hline $\begin{array}{l}\text { NSMCE3 (non-structural maintenance of } \\
\text { chromosome element } 3 \text { homolog) }\end{array}$ & Autosomal recessive & Immunodeficiency \\
\hline OAS1 (oligoadenylate synthetase 1) & Autosomal dominant & Pulmonary alveolar proteinosis \\
\hline SLC7A7 (solute carrier family 7 member 7) & Autosomal recessive & Surfactant disorder \\
\hline TBX4 (T-box transcription factor 4) & Autosomal dominant & Acinar dysplasia \\
\hline TMEM173 (transmembrane protein 173) & Autosomal dominant & $\begin{array}{l}\text { Lung fibrosis with general } \\
\text { inflammation }\end{array}$ \\
\hline
\end{tabular}

The clinical presentation of chILD varies, ranging from mild nonspecific symptoms to a very severe clinical picture. Usually, the earlier the disease onset, the more severe the presenting symptoms [100]. 
During the neonatal period, in term neonates, chILD may occur shortly after birth, with unexplained respiratory distress requiring intubation and ventilation [101]. In born preterm infants, chILD presents with acute respiratory distress that is more severe and is expected because of prematurity [101].

During the first two years of life [102,103], common presentations include asymptomatic forms or nonspecific respiratory signs and symptoms, such as dyspnea, polypnea, dry cough, wheezing, recurrent respiratory infections, and exercise intolerance [101]. Moreover, severe respiratory distress usually triggered by viral infections may occur. Older children can show tachypnoea, hyperoxia, digital clubbing, and/or cyanosis during exercise or at rest [101,104,105]. As reported in Table 3, a severity score of disease was proposed by Fan et al. [106].

Table 3. Severity-of-illness score according to Fan et al. [106].

\begin{tabular}{l}
\hline 1. Asymptomatic \\
\hline 2. Symptomatic, normal room air oxygen saturation under all conditions \\
\hline 3. Symptomatic, normal resting room air saturation but abnormal saturation $(90 \%)$ with \\
sleep or exercise \\
\hline 4. Symptomatic, abnormal resting room air saturation $(90 \%)$ \\
\hline 5. Symptomatic with pulmonary hypertension \\
\hline
\end{tabular}

At the initial investigation, the chest radiograph may be normal or reveal nonspecific alterations [107]. The role of functional lung testing in infants is unclear: in older children, a restrictive pattern is usually detected. Within the diagnostic workup, blood tests including genetic evaluation, immunological profile, and autoantibody studies are recommended, and environmental organic dust exposures could be considered.

When chILD is suspected clinically, chest computed tomography (CT) scanning is the gold standard to evaluate the presence and extent of lung damage; however, only in some cases can it be diagnostic [107]. Common radiologic patterns in chILD are widespread ground-glass attenuation, sometimes coupled with intralobular lines; irregular interlobular septal thickening; honeycombing; and, less frequently, large subpleural air cysts (usually located in upper lobes adjacent to areas of ground-glass opacities) [18,108-110]. Invasive testing, such as bronchoscopy with bronchoalveolar lavage (BAL), may be diagnostic in pulmonary hemorrhage syndromes, alveolar proteinosis, and eosinophilic lung disease, and a normal cell differential can rule out hypersensitivity pneumonitis [17]. Endobronchial and transbronchial biopsies are rarely performed in chILD and are not recommended unless a specific diagnosis is suspected, such as pulmonary alveolar microlithiasis or sarcoid granulomas. Lung biopsy is the last step in the diagnostic workup. The timing and need for lung biopsy in chILD remain controversial; biopsy prior to steroid treatment is recommended to minimize risk to wound healing and to expedite specific chILD treatments.

A multidisciplinary approach for diagnosis and follow-up is mandatory in chILD. Pediatricians, pediatric pulmonologists, radiologists, geneticists, and pediatric surgeons are the crucial players $[17,18]$.

The prognosis of chILD is variable, ranging from complete recovery in neuroendocrine cell hyperplasia during infancy and pulmonary interstitial glycogenosis to a mortality rate that approaches $100 \%$ in alveolar capillary dysplasia. The overall mortality rate is around $15 \%$, with a variable outcome in infants [106,111-114].

The standard treatment of chILD is mainly supportive and based on oxygen supplementation, and/or ventilation, and respiratory physiotherapy $[17,18]$. Nutritional support is mandatory to maintain an adequate caloric intake to prevent failure to thrive. From a pediatric surgery point of view, most of these patients require tracheostomy in the few first months of life, followed by enteral nutritional supply by gastrotomy. With time and in order to protect the lung tissue, most of the children need an antireflux procedure. In 
some patients, when bullous emphysema and hypertensive pneumothorax occur, leading to ventilation failure, surgical resection may be necessary to ensure lung growth.

Empirical medical therapy with anti-inflammatory and immunomodulatory drugs including corticosteroids, hydroxychloroquine, and azithromycin is usually used with varying degrees of efficacy $[17,18]$. New antifibrotic drugs currently proposed in adults, including pirfenidone and nintedanib, may represent new therapy options for certain forms of chILD in the future. Lung transplant is a therapeutic option for children with end-stage chronic respiratory failure. The outcome and survival are similar to those reported in other lung conditions [115].

Preclinical and clinical studies support a potential beneficial role of cell therapy to prevent the chILD progression [116]. Additionally, cell therapy could be useful to promote the repair and regeneration of the impaired lung.

\section{Preclinical and Clinical Studies}

\subsection{Preclinical}

ILD is a group of diseases that includes several chronic lung diseases characterized by varying degrees of inflammation and fibrosis. Most ILDs are idiopathic, including idiopathic pulmonary fibrosis (IPF). In order to understand the pathogenetic mechanisms of pulmonary fibrosis and identify possible therapeutic targets, several animal models have been developed that are capable of mimicking the human characteristics of the disease. The bleomycin model is the most used and best characterized model that reproduces different cellular and molecular mechanisms involved in IPF and in other fibrotic ILDs $[117,118]$. Bleomycin is a complex glycopeptide [119] isolated from Streptomyces verticillus, an actinobacteria strain [120]. This drug showed usefulness as an anticancer in several carcinomas and lymphomas [121]. However, the use of this drug has been limited due to its toxicity in organs such as the lung. These adverse events promoted the use of this agent to induce animal models of pulmonary fibrosis [122]. Initially, drug administration induces direct damage of alveolar epithelial cells, promoting the production of alveolar inflammatory cells within the first seven days [123]. Subsequently, these cells are eliminated and the proliferation of fibroblasts is induced, with the consequent development of pulmonary fibrosis [124]. Notably, the bleomycin model is characterized by an overlap between the inflammatory and fibrotic models. Initially, the model induces an early inflammatory phase that switches to the fibrotic state after 5-7 days. The strong inflammatory response induced by bleomycin may take up to 10 days before complete elimination. The fibrotic phase begins when the inflammatory process has subsided. After two weeks, the resolution of the fibrosis starts. Therefore, in this animal model, the "time window" during which it is possible to test the fibrogenic mechanisms and the antifibrotic drugs action's is relatively short $[125,126]$. Another experimental model that is used is induced by fluorescein isothiocyanate (FITC), which involves the intratracheal administration of FITC in both C57Bl/ 6 and Balb/c mice $[127,128]$. FITC caused infiltration of mononuclear and neutrophil cells into the lung interstitium, inducing pulmonary fibrosis by day 21 , as also observed in the bleomycin model [128]. Silica-induced lung fibrosis is another model used to reproduce fibrotic nodules that resemble lesions that develop following occupational exposure to mineral dust and particulate aerosols [129]. Silica is trapped in the lung where a toxic and inflammatory response is activated, inducing the alveolal accumulation of proteins and neutrophilia, responsible for activating a fibrotic response $[130,131]$. Several transgenic strains mimic the characteristics of pulmonary fibrosis, such as human collagenase directed by the haptoglobin promoter [132], PDGF-B directed by the surfactant protein C (SP-C) promoter, human transforming growth factor-alpha (TGF- $\alpha$ ) directed by the SP-C promoter [133], interleukin (IL)-11, and IL-13 directed by the bronchiolar exocrine/club cells 10-kDa (CC10) protein promoter $[134,135]$. The transgenic model, however, has the disadvantage of not accurately recreating the multigenic environment of natural pulmonary fibrosis. Additionally widely used are models involving the use of adenoviral vectors, which exploit gene transfer mediated by adenoviruses to overexpress cytokines and chemokines such as 
granulocyte-macrophage colony-stimulating factor (GM-CSF) [135], tumor necrosis factoralpha (TNF- $\alpha$ ) [136], transforming growth factor-beta 1 (TGF- $\beta 1$ ) [137], and IL-1 $\beta$ [138]. These transgenes persist for 21 days and cause major fibrotic lesions in rodents, proving useful models for studying the pathogenesis of this disease [139]. Contrarily, the use of lentiviral vectors permanently transfers the transgenes in different cells of the lung, thus allowing analysis of the effect of the overexpression of the transgene in the long term. These models are useful for studying the effect of the gene product at the onset and during pulmonary fibrosis [140].

\subsubsection{Animal Models of Pulmonary Fibrosis}

The use of MSCs in clinical practice is now a field of considerable interest. However, most preclinical studies employed human BM-MSCs to treat asthma [141], acute lung injury [142], pulmonary fibrosis [143], and acute respiratory distress syndrome [144]. In this context, Balogh et al. [145] evaluated the immunomodulatory role of MSCs taken from bronchoalveolar lavage fluid (BALF) from patients with hypersensitivity pneumonitis (HP) compared to normal MSCs isolated from healthy subjects. Immunophenotyping by flow cytometry and confocal laser scanning microscopy demonstrated that BALF MSCs have reduced levels of CD105, CD73, and CD90. Therefore, these cells, compared to the MSCs isolated from control subjects, showed a loss of immunosuppressive activity. In order to evaluate the role of bronchoalveolar MSCs on T-cell function in vitro, phytohemagglutinin (PHA)-stimulated peripheral blood mononuclear cells (PBMCs) were co-cultured with normal or HP-derived BALF MSCs. Measurement of 5,6-carboxyfluorescein-diacetat succinimidyl ester (CFSE) positivity by flow cytometry demonstrated that normal MSCs were able to reduce T-cell proliferation, whereas HP-derived MSCs did not have a significant immunosuppressive effect on normal or HP T lymphocytes. When T cells were cultured with normal MSCs or $\mathrm{HP}$, reduced proliferation and activation of $\mathrm{CD}^{+}$and $\mathrm{CD}^{+} \mathrm{T}$ cells were observed with reduced CD25 positivity mediated by normal MSCs. In contrast, HP-derived MSCs did not induce division energy in either T-cell subtype. Therefore, these results demonstrate that healthy MSC s can affect HP-derived activated T cells, suggesting the use of these cells as a potential therapeutic approach for this type of ILD [145].

Given the positive role of MSC transplantation in reducing pulmonary fibrosis [146], Chen et al. [147] evaluated the effects of adipose-derived MSCs (AD-MSCs) in rats in which pulmonary fibrosis was silica-induced. For the study, AD-MSCs were taken from the adipose tissue of rats and cultured in vitro. In order to study the antifibrotic effects of AD-MSCs, the animals underwent oral-tracheal intubation with a silica suspension $(50 \mathrm{mg} / \mathrm{mL})$ to induce the pulmonary fibrosis pattern. After $24 \mathrm{~h}$, the animals were treated intravenously with AD-MSCs $\left(1 \times 10^{6}\right.$ cells $\left./ \mathrm{kg}\right)$. Twenty-eight days after the transplant, the animals were sacrificed and the organs were isolated for histopathological investigations. In lung tissue, treatment with AD-MSCs markedly reduced the expression levels of TNF- $\alpha$, IL-6, and IL-10; conversely, it increased IL-1 $\beta$ expression levels. Treatment with AD-MSCs reorganized the alveolar structure that had been severely destroyed by exposure to silica, reducing inflammatory cell infiltration phagocytic cells and silicon nodules. Additionally, AD-MSCs reduced silica-induced apoptosis in lung tissue cells. A decrease in caspase-3 was observed due to the decrease in the B-cell lymphoma protein-2-associated X (Bax)/B-cell lymphoma protein 2 (Bcl-2) ratio in the treatment group. These results further confirmed that AD-MSCs appear to exert a lung protective effect and reduce the apoptosis process in the animal model of pulmonary fibrosis [147].

Most preclinical and clinical studies evaluated the efficacy of BM-MSCs and ADMSCs in IPF. Cores et al. [148] instead investigated the effects of adult lung spheroid cells (LSCs) as a source of stem cells for allogeneic cell therapy in pulmonary fibrosis. For the study, lung outgrowth cells from the distal region of the lungs were harvested from male Wistar-Kyoto rats (MHC haplotype, $\mathrm{RT}^{\mathrm{I}}$ ), used as LSCs donors. In order to evaluate the proangiogenic effects in vitro, human umbilical vein endothelial cells (HUVECs) were cultured in media conditioned with LSCs. The data showed that LSCs, 
by means of paracrine action, stimulated angiogenesis by reducing fibrosis. To reproduce an allogeneic cell transplantation model, Wistar-Kyoto and Brown Norway female rats (MHC haplotype, $\mathrm{RT}^{\mathrm{II}}$ ) as syngeneic and allogeneic recipients, respectively, were used for the experiment. The animals were treated with bleomycin $(1.5 \mathrm{U} / \mathrm{kg})$ intratracheally on day 0 to induce the pulmonary fibrosis pattern. The following day, the rats were treated with LSCs $\left(5 \times 10^{6}\right.$ cells $)$ intravenously via the tail vein, while the control group received saline. Both allogeneic and syngeneic LSCs alike attenuated the onset of fibrosis and the deposition of connective tissue and collagen in the post-injury lungs. LSC treatment also protected the pneumocytes from bleomycin-induced injury, reduced apoptosis in the lungs, and induced angiogenesis. Expression data on cytokine levels, such as inflammatory cytokine, immune response, wound healing, and epithelial proliferation, demonstrated that the treatment creates no systemic immune or inflammatory response. Furthermore, data on the expression levels of T lymphocytes in the lung showed that cell therapy did not induce any local immune response. Therefore, this evidence suggests that allogeneic LSC treatment can be considered safe and efficacious in slowing the progression and severity of fibrosis [148].

In the above-described studies, MSCs were administered intratracheally or intravenously. MSCs administration appears to decrease inflammation and fibrosis in several chronic lung disease models of newborn rodents. Despite the benefits of this therapeutic approach, the route of administration and the optimal dose in newborns still need to be determined. Liu et al. [149] surveyed the dose-dependent effects of intranasal MSCs release versus the intraperitoneal route in an early neonatal lung injury model. The long-term mechanical and histological effects of human umbilical cord derived MSCs (hUC-MSCs) were evaluated in the study. In order to induce lung damage, neonatal mice with severe combined immunodeficiency were exposed to hyperoxic conditions from birth until postnatal day 7, while one group was maintained in normoxic conditions as a control group. On the fifth postnatal day, during the phase of intense acute lung injury, the pups were subjected to the administration of cell suspension $\left(0.1,0.5\right.$, or $1 \times 10^{6}$ cells $/ \mathrm{kg}$ in $20 \mu \mathrm{L}$ of phosphatebuffered saline) via the intranasal or intraperitoneal route. Instead, sham normoxic controls received $20 \mu \mathrm{L}$ of phosphate-buffered saline either intranasally or intraperitoneally. Animals were sacrificed either $48 \mathrm{~h}$ or 8 weeks after cell transplantation to assess the short- and long-term effects of cell therapy. Systemic (intraperitoneal) administration of hUC-MSCs in neonatal mice exposed to hyperoxia restored lung compliance, pressure-volume loop, and elastance in a dose-dependent manner 8 weeks after transplantation. At the highest dose $\left(1 \times 10^{6}\right.$ cells $\left./ \mathrm{kg}\right)$, intraperitoneal MSC transplantation effectively increased the thickness of the alveolar septum, probably remodeling the interstitial matrix. Conversely, transplantation of hUC-MSCs via the intranasal or intraperitoneal route at lower doses had no significant effects on lung function or alveolar remodeling. Therefore, the results of this study highlight the beneficial effects of hUC-MSCs transplantation on tissue recovery and lung function following chronic neonatal injury. However, future studies are needed to evaluate the long-term safety of systemic transplantation with MSCs, especially when considered for pediatric use [149].

Mansouri et al. [150] investigated the therapeutic effects of EVs isolated from BMMSCs in an animal model of IPF. In order to induce the IPF model, C57BL/ 6 mice were subjected to a single intratracheal administration of bleomycin sulfate ( $50 \mu \mathrm{L}, 3 \mathrm{U} / \mathrm{kg})$, while the control group received saline $(50 \mu \mathrm{L})$. Simultaneously, the animals were treated with a single dose of EVs ( $200 \mu \mathrm{L}$; dose, $5 \times 10^{6}$ MSC equivalents; $\sim 8.6 \times 10^{8}$ particles) or with EVs-free iodixanol vehicle only (control group). EVs were intravenously administered via the tail vein. Animals were evaluated on days 7,14 , or 28 by cytometric, histological and/or quantitative PCR analysis. A single dose of BM-MSCs-derived EVs attenuated bleomycin-induced damage, improving lung morphology, reducing collagen deposition, and restoring lung architecture. After both 7 and 14 days, treatment with BM-MSCsderived EVs increased the populations of alveolar macrophages and infiltrated monocytes, while reducing the classical proinflammatory monocytes. The same immunomodulatory 
effect was demonstrated in myeloid cells derived from the BM. In order to investigate the modulatory effect of EVs on the BM-myeloid/monocyte cell lineage phenotype, these cells were preconditioned with BM-MSCs-derived EVs ex vivo. Proteomic analysis of this cell line, performed by liquid chromatography-tandem mass spectrometry (LC-MS/MS), demonstrated that treatment with BM-MSCs-derived EVs exerts its protective effects, at least in part, by reprogramming the phenotypic profile of myeloid cells derived from BM toward a nonclassical phenotype. Subsequently, BM-derived myeloid cells preconditioned with EVs ex vivo were administered to mice with pulmonary fibrosis. After receiving bleomycin, animals received two doses of BM-derived myeloid cells preconditioned with EVs on days 0 and 3. Treatment with this cell population reduced collagen deposition, restored lung architecture, and reduced inflammation. These data demonstrate that the effects of BM-MSCs-derived EVs mediated, at least part, the myeloid cells reprogram toward a proregulatory phenotype, thus reducing infiltration into the lungs of proinflammatory and profibrotic monocytes [150].

\subsubsection{Animal Models of BPD}

Bronchopulmonary dysplasia (BPD) is a complex chronic lung disease that is common in premature infants, especially in very low birth weight and extremely low birth weight infants with an incidence of $30-40 \%$ and $54.1 \%$, respectively [2]. In the early postnatal period of preterm infants, the pulmonary cells in the late canalicular or early saccular stage are in a highly proliferative state, leading to the lack effective alveolar gas exchange [2]. $\mathrm{BPD}$ results in a lung injury and abnormal lung repair, characterized by a decrease in the number of alveoli, abnormal morphology, uneven ventilation distribution, and abnormal development of the vascular system of the lung [2]. Similarly to chILD, the consequences of lung immaturity remain through-out childhood and can often lead to chronic respiratory diseases characterized by parenchymal fibrosis and alveolar and vascular growth block [2,151], For this reason, BPD may represent a model to document the efficacy of MSCs treatment in ILD.

Moreira et al. [152] investigated the efficacy and safety of intranasal MSCs infusion in a BPD model. The cells were obtained from the gelatinous tissue of Wharton's umbilical cord from a healthy human infant. The rat pups at postnatal day 4 were randomly divided into four groups. One group was maintained in normoxic conditions $\left(21 \% \mathrm{O}_{2}\right)$ for 21 days (controls group). The remaining groups underwent continuous hyperoxia $\left(60 \% \mathrm{O}_{2}\right)$ for 4 days to induce the BPD model. In the study, one group of BPD rats received nothing (BPD group), one group was treated with vehicle, and one group received MSCs ( $20 \mu \mathrm{L}$ containing $5 \times 10^{5}$ cells $/ \mathrm{kg}$ ) on days 4,12 , and 20. Morphometric pulmonary analyses showed that the administration of MSCs restored alveolarization, vascularization, and pulmonary remodeling, which, on the contrary, are altered in hyperoxic conditions. In pulmonary homogenates, treatment with MSCs increased vascular endothelial growth factor mRNA expression compared to the control group, which did not change compared to the BPD group. An analysis of lung tissue genes and proteins suggested that MSCs exert their beneficial effects, at least in part, by modulating genes involved in angiogenesis, immunomodulation, wound healing, and cell survival. Therefore, the data from this study showed that MSCs can improve the outcomes of BPD infants. Notably, these findings demonstrated that the experimental intranasal route of administration is a feasible, noninvasive, and efficacious route that may have clinical applicability [152].

The beneficial effect of MSCs-derived EVs was also demonstrated by Portionato et al. [153] in a mouse model of BPD induced by exposure to hyperoxia in the first 2 weeks postnatally. The newborn rats were randomly divided into four groups: one group of animals was raised for six weeks in normoxic conditions, as a control group. The experimental groups were exposed to $60 \%$ hyperoxia for 2 weeks, and for another 4 weeks to normoxic conditions. Half of the animals in the experimental group received saline (sham-treated animals), while the others were treated with MSC-derived EVs $\left(0.64 \times 10^{10}\right.$ particles $)$ or with MSCs $\left(6 \times 10^{6}\right.$ cells $\left./ \mathrm{kg}\right)$ on postnatal days 3,7 , and 10 via intratracheal administration. 
MSCs-derived EVs delivery increased the number of alveoli, their surface area, and the proliferation index, which were decreased in the hyperoxic conditions. Furthermore, the treatment reduced mean alveolar volume, mean linear intercept, and fibrosis. The medial thickness index for vessels $<100 \mu \mathrm{m}$ reduced in MSCs-derived EVs, which increased in hyperoxic rats compared to the normoxic group. EVs also prevented the reduction in CD163-positive macrophages in both interstitial/alveolar and perivascular populations, which was instead induced in hyperoxic conditions. Intratracheal administration appears to be intriguing for translation in the future, probably due to its capacity to directly target organs for treatment. These data support the use of MSCs-derived EVs as a cell-free approach to improve altered alveolarization and remodeling of the pulmonary artery even after long-term treatment in preterm-born human infants [153]. These findings suggested that most of MSCs' beneficial effects are mediated by paracrine signaling, pointing to the feasibility of using MSC secretome as a therapeutic tool. However, both the toxicity and biodistribution of MSCs-derived EVs need further investigation in animal models before they can be used as first-in-human patients.

Th paracrine effects of MSCs are mediated by the release of immunomodulatory and growth factors that have been identified in the CM [154]. In this regard, Hansmann et al. [155] evaluated the effects of the CM in BPD management. In order to induce the BPD pattern, newborn FVB mice were exposed to $75 \% \mathrm{O}_{2}$ for 14 days, while a control group was kept in normoxic conditions. After 14 days of exposure to hyperoxic conditions, the animals were treated with a dose of BM-MSCs-derived CM isolated from the femurs and tibias of FVB mice, at a concentration of $10 \mu \mathrm{g}$ of BM-MSCs-derived CM protein per mouse. A group of animals subjected to hyperoxic conditions, instead, was treated with mouse lung fibroblasts (MLF)-derived CM as a control group. CM was administered intravenously either through the superficial temporal vein or the jugular vein. Compared to treatment with MLF-derived CM, the administration of BM-MSCs-derived CM improved the hyperoxiainduced pathogenesis of BPD. BM-MSCs-derived CM reduced alveolar damage, septal thickening, and myofibroblast infiltration, and improved lung function. Treatment with BM-MSCs-derived CM attenuated pulmonary hypertension, right ventricular hypertrophy, and peripheral pulmonary artery pressure muscularization related to hyperoxia-induced BPD. Furthermore, pulmonary artery pruning lead by hyperoxia was ameliorated by a single intravenous dose of MSC-derived CM, highlighting the angiogenic and vasculogenic effect of MSC-derived CM. Therefore, the use of CM derived from MSCs could be a valid therapeutic option for BPD and other chronic lung diseases; however, future studies will be needed to understand the mechanisms underlying their beneficial effects [155].

The results of all these studies (Table 4) showed the beneficial effects MSCs transplantation in tissue recovery and lung function following pediatric fibrotic lung disease. These findings also highlight that MSC s' beneficial effects are mediated, at least in part, by paracrine signaling, demonstrating the feasibility of using MSC secretome as a therapeutic tool. However, further preclinical studies are required to evaluate the long-term safety of systemic transplantation with MSCs and the toxicity and biodistribution of MSCs secretome before it can be used in humans, especially when considered for pediatric use. 
Table 4. Synthesis of the studies that evaluate the role of MSCs in several animal models of pediatric pulmonary fibrosis (PF).

\begin{tabular}{|c|c|c|c|c|c|c|}
\hline In Vivo Models & Cell Therapy & Dose & $\begin{array}{l}\text { Route of Ad- } \\
\text { ministration }\end{array}$ & Intervention & Resuts & Ref. \\
\hline $\begin{array}{l}\text { Newborn } \\
\text { Sprague-Dawley rats } \\
\text { Hyperoxia-induced BPD }\end{array}$ & $\begin{array}{l}\text { Human umbilical cord } \\
\text { Wharton's Jelly-derived } \\
\text { MSCs transplantation }\end{array}$ & $5 \times 10^{5}$ cells $/ \mathrm{kg}$ & $\begin{array}{l}\text { Intranasal } \\
\text { delivery }\end{array}$ & $\begin{array}{l}\text { Multiple administration } \\
\text { on days } 4,10 \text {, and } 20, \\
\text { after } 3 \text { weeks from } \\
\text { induction }\end{array}$ & $\begin{array}{c}\text { Improvement of alveolarization, vascularization, } \\
\text { and pulmonary remodeling } \\
\text { Increased of the mRNA expression of vascular } \\
\text { endothelial growth factors } \\
\text { Modulation of genes involved in angiogenesis, } \\
\text { immunomodulation }\end{array}$ & [152] \\
\hline $\begin{array}{c}\text { Severe combined } \\
\text { immunodeficiency- } \\
\text { beige mice } \\
\text { Hyperoxia-induced BPD }\end{array}$ & $\begin{array}{l}\text { hUC-MSCs } \\
\text { transplantation }\end{array}$ & $\begin{array}{c}0.1,0.5, \text { or } \\
1 \times 10^{6} \text { cells } / \mathrm{kg}\end{array}$ & $\begin{array}{l}\text { Intranasal or } \\
\text { intraperitoneal } \\
\text { administration }\end{array}$ & $\begin{array}{l}\text { Single dose on postnatal } \\
\text { day } 5 \text {, during induction }\end{array}$ & $\begin{array}{c}\text { Recovery of lung compliance, pressure-volume } \\
\text { loop and elastance } \\
\text { Enhancement of the thickness of the alveolar } \\
\text { septum }\end{array}$ & [149] \\
\hline $\begin{array}{l}\text { Wild-type } \\
\text { Sprague-Dawley rats } \\
\text { Hyperoxia-induced BPD }\end{array}$ & $\begin{array}{l}\text { MSCs-derived EVs } \\
\text { or } \\
\text { MSCs administration }\end{array}$ & $\frac{0.64 \times 10^{10} \text { particles }}{6 \times 10^{6} \text { cells } / \mathrm{kg}}$ & $\begin{array}{l}\text { Intratracheal } \\
\text { delivery }\end{array}$ & $\begin{array}{l}\text { Multiple administration } \\
\text { on days } 3,7 \text {, and } 10 \text { after } \\
\text { induction }\end{array}$ & $\begin{array}{l}\text { Enhancement of the number of alveoli, alveolar } \\
\text { surface area, and proliferation index } \\
\text { Decrease of the mean alveolar volume, mean } \\
\text { linear intercept, and fibrosis was decreased } \\
\text { Reduction the medial thickness index for vessels }\end{array}$ & [153] \\
\hline $\begin{array}{l}\text { Mouse pups FVB } \\
\text { Hyperoxia-induced BPD }\end{array}$ & $\begin{array}{l}\text { BM-MSCs-derived CM } \\
\text { or } \\
\text { MLF-derived CM }\end{array}$ & $\begin{array}{l}\mathrm{CM} \text { containing } 10 \mu \mathrm{g} \\
\text { protein }\end{array}$ & $\begin{array}{l}\text { Intravenous } \\
\text { administration }\end{array}$ & $\begin{array}{l}\text { A single dose after } 14 \\
\text { days of induction }\end{array}$ & $\begin{array}{l}\text { Reduction of the alveolar damage, septal } \\
\text { thickening, myofibroblast infiltration } \\
\text { Improvement of the lung function } \\
\text { Reduction of the pulmonary hypertension, right } \\
\text { ventricular hypertrophy, and peripheral } \\
\text { pulmonary artery pressure muscularization }\end{array}$ & [155] \\
\hline
\end{tabular}

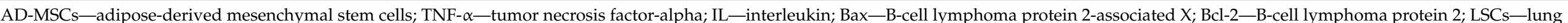

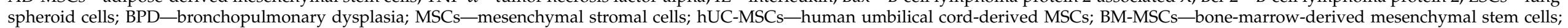
EVs—extracellular vesicles; CM—conditioned medium; MLF—-mouse lung fibroblasts; PF—pulmonary fibrosi. 


\subsection{Clinical Studies}

Recent evidence showed that MSCs represent a valid therapeutic approach for the treatment of pulmonary diseases in adult patients, including chronic obstructive pulmonary disease, silicosis, acute respiratory distress, and idiopathic pulmonary fibrosis [146,156-159]. To date, in the pediatric population, the therapeutic effects of MSCs on respiratory diseases were evaluated in BPD that may be considered as potential model of interstitial diseases and thus discussed.

\subsubsection{Phase 1 Clinical Trials}

Chang et al. [160] in a phase I clinical trial (NCT01297205), evaluated the safety, feasibility, and efficacy of the transplant of human umbilical cord blood derived MSCs (hUCB-MSCs) in premature BPD children. In the study, the recruited nine infants of gestational age 24-26 weeks (extremely premature) and at high risk of developing BPD, with damaged respiratory conditions and on ventilatory support. Three infants received a low dose of hUCB-MSCs $\left(1 \times 10^{7}\right.$ cells $\left./ \mathrm{kg}\right)$, and six received high-dose hUCB-MSCs $\left(2 \times 10^{7}\right.$ cells $\left./ \mathrm{kg}\right)$. Cells were intratracheally delivered into the left and right lungs. Cell transplantation was found to be safe: neither serious adverse effects nor dose-limiting toxicity up to 84 days following transplantation were observed. Only three out of nine children developed moderate BPD, highlighting the beneficial effects of cell transplantation. hUCB-MSCs transplantation also reduced the duration of intubation, the mean respiratory index 3 days after transplantation, steroid use, and positive airway pressure. Additionally, compared to baseline or day 3 after cell infusion, at day 7 in tracheal aspirates, treatment reduced levels of IL-1, IL-6, IL-8, IL-10, matrix metalloproteinase (MMP)-9, TGF- $\beta$, and TNF- $\alpha$. Therefore, the data from this study demonstrated that intratracheal hUCB-MSCs delivery may be safe and feasible in preterm infants, and may be effective in reducing BPD severity [160].

A long-term follow-up study is underway (NCT01632475) to evaluate the safety and feasibility of the long-term treatment with these cells of premature infants with BPD enrolled in the previous trial. The primary aim of the study led by Ahn et al. [161] is to evaluate the long-term safety of MSC transplantation in infants up to 24 months of age. Only one in nine children died six months after treatment, but this adverse event was not related to MSC transplantation. None of the remaining infants experienced treatmentrelated adverse events. Therefore, intratracheal transplantation with hUCB-MSCs would appear to be safe in premature infants at high risk of developing BPD up to 2 years of age. Compared to the comparison group, infants treated with hUCB-MSCs no longer needed supplemental oxygen. After 18-24 months, the infants demonstrated weight gain that could be related to better long-term neurodevelopmental outcomes [161].

\subsubsection{Phase 2 Clinical Trials}

In order to further evaluate the efficacy and safety of stem cell therapy for BPD, a long-term clinical trial is underway for children up to the age of 5 years (NCT02023788) for patients who completed the earlier part of the previous phase I clinical trial (NCT01632475). Ahn et al. [162] performed a larger, double-blind, randomized, phase II clinical trial aimed at evaluating the therapeutic efficacy of transplantation with hUCB-MSCs (NCT01828957). The study enrolled 60 extremely premature infants, aged between 23 and 28 gestational weeks, with BPD. In the experimental group, infants received hUCB-MSCs in step 6 $\left(1 \times 10^{7}\right.$ cells $\left./ \mathrm{kg}\right)$, administered intratracheally via a gavage tube in two fractions in the left and right lungs. The placebo group only received an equal volume of saline. Treatment with hUCB-MSCs reduced levels of IL-1 $\beta$, IL-6, IL-8, TNF- $\alpha$, and MMP-9 at day 7 compared to the control group. However, the treatment did not improve the death outcome or disease progression. Treatment with hUCB-MSCs improved the outcome of severe BPD from 53\% to $19 \%$ in the 23-24 gestational weeks subgroup of infants. Conversely, the severity of the disease was not improved in the subgroup of patients aged from 25 to 28 gestational weeks. Therefore, these data showed that hUCB-MSCs transplantation is effective and feasible; 
however, the small number of samples does not allow establishing the efficacy in preterm infants aged from 23 to 28 gestational weeks [162]. Therefore, a further larger phase II study is underway recruiting infants aged from 23 to 24 gestational weeks (NCT03392467). Sixty premature infants within 13 days of postnatal age were recruited in the trial. The experimental group will receive hUCB-MSCs $\left(1 \times 10^{7}\right.$ cells $\left./ \mathrm{kg}\right)$, while one group will receive a saline solution (control group). The results of this study will help to understand the efficacy and safety of hUCB-MSCs for the treatment and prevention of severe BPD in premature infants. The subjects who passed phase II of the trial (NCT01828957) were recruited into the follow-up study, which aims to monitor participants up to the age of 5 years (NCT01897987). The main trial aim is to evaluate the respiratory outcome following transplantation with hUCB-MSCs compared to the control group.

Another open-label dose-escalation trial (phase I/II), led by Powell et al. [163] aimed to investigate the safety of single-dose intratracheal administration of hUCB-MSCs in extremely low birth weight preterm infants with BPD (NCT02381366). The study enrolled 12 premature infants born at 23-27 weeks of gestation with a high risk of BPD. One group of infants received hUCB-MSCs at the lowest dose $\left(1 \times 10^{7}\right.$ cells $\left./ \mathrm{kg}\right)$, and the other group at the highest dose $\left(2 \times 10^{7}\right.$ cells $\left./ \mathrm{kg}\right)$. The administration of hUBC-MSCs, at both doses, was well-tolerated by all patients with no signs of toxicity during the $72 \mathrm{~h}$ of observation. No serious adverse events were recorded during the 84 days of the study. Therefore, treatment with hUCB-MSCs proved to be safe and feasible [163].

Based on these promising results, Wu et al. [9] performed a phase II study, with respective control groups, to further investigate the safety and efficacy of the use of allogeneic hUCB-MSCs in children with severe BPD (NCT03601416). The study recruited 72 children up to the age 1 year with moderate or severe BPD undergoing traditional supportive treatments. Participants were treated intravenously with low-dose $\left(2.5 \times 10^{6}\right.$ cells $\left./ \mathrm{kg}\right)$ or high-dose $\left(5 \times 10^{6}\right.$ cells $\left./ \mathrm{kg}\right)$ hUCB-MSCs. The end date of the trial is expected to be December 2021. The study results will help prove the long-term safety and efficacy of hUCB-MSCs. They will also allow the ability of treatment to improve lung structure impairment by exploring its potential therapeutic use in the management of severe childhood BPD [9].

\subsubsection{Active Clinical Trials}

Currently, 13 additional clinical trials of MSCs therapy for BPD have been registered with ClinicalTrials.gov. Among them, five phase I studies (NCT02443961, NCT03631420, NCT01207869, NCT04255147, and NCT03683953) are active in not-recruiting status. All five registered clinical trials involve the administration of MSC via intratracheal or intravenous routes at doses ranging from 1 to $30 \times 10^{6}$ cells $/ \mathrm{kg}$ of body weight in children (1-37 weeks) at high risk of BPD. Seven phase I/II studies (NCT03774537, NCT03558334, NCT03873506, NCT04003857, NCT03378063, NCT04062136, and NCT03645525) are in recruiting status. These trials foresee the administration of hUCB-MSCs by an intratracheal or intravenous route at doses ranging from $1 \times 10^{6}$ to $2 \times 10^{7}$ cells $/ \mathrm{kg}$ of body weight in children (from 3 days to 5 years of age) at high risk of BPD. The study results will better assess the safety, feasibility, and efficacy of MSCs for the prevention and treatment of premature infants at high risk of BPD.

\subsubsection{Terminated Clinical Trial}

A placebo-controlled trial (NCT03857841) intended to evaluate the safety of intravenous infusion of BM-MSCs-derived EVs (UNEX-42) in preterm neonates (from 3 to 14 days postnatal) at high risk of BPD. The BM-MSCs-derived EVs were administered at doses of 20, 60 , or 200 pmol phospholipid/ kg body weight. The results of this study will be useful for understanding the safety and tolerability of BM-MSCs-derived EVs up to 10 months after treatment. Furthermore, at the end of this post-treatment phase, patients will be included in the next phase and will be monitored until they reach 1 year of age to also evaluate the long-term effects of pediatric treatment with cell derivatives. 


\subsubsection{Clinical Trial in Child with Chronic Respiratory Failure}

In a brief report, Calcaterra et al. [164] isolated MSCs from the lung tissue of a male infant presumed to have congenital lobar emphysema and filamin A (FLNA) gene mutation. MSCs isolated from this child's lung tissue exhibited the same characteristics as MSCs and the ability to differentiate into osteoblasts. Instead, these MSCs, compared to the control BM-MSCs, showed low migration capacity, which could be linked to FLNA deficiency. Therefore, these data highlight the important role that may have been played by dysfunctional lung MSCs in impaired lung development and in the formation of emphysematous lesions. In addition, they may also have been responsible for the altered matrix remodeling that induced progressive fibrotic lung disease [164]. Based on this evidence, in a clinical study performed by Pelizzo et al. [11], the effects of repeated intravenous administration of allogeneic BM-MSCs were evaluated in a child with progressive obstructive pulmonary disease associated with an FLNA gene mutation [11]. The mutation in this gene was recently associated with lung growth abnormalities, which, in several cases, progress to interstitial lung disease [165]. In this work, a 32-day old male child was hospitalized with respiratory distress and suspected congenital lung malformation. He underwent lobar resection of the damaged lung segments, noninvasive mechanical ventilation at 11 months, followed by a tracheostomy after 1 month. Therefore, at the age of 18 months, due to severe and irreversible chronic respiratory failure, the child underwent salvage therapy with allogeneic BM-MSCs. The allogeneic BM-MSCs were isolated and expanded ex vivo from healthy donor bone marrow. The child received four infusions of MSCs $\left(1 \times 10^{6}\right.$ cells $\left./ \mathrm{kg}\right)$ intravenously 4 weeks apart. Before each infusion and 1 month after the last one, peripheral blood and mononuclear cells were collected. Treatment with allogeneic MSCs greatly improved the child's respiratory condition. Furthermore, the positive effects observed after the second dose suggested the need for serial administrations rather than single injections. The mechanisms used by MSCs to exert these beneficial effects are, at least in part, mediated by paracrine immunomodulatory capacity on the recipient lung tissue. After the second MSCs infusion, decreased levels of Th17 and the consequent normalization of the $\mathrm{T}_{\text {reg }} /$ Th17 balance were observed, which is usually dysregulated in various lung diseases. The increase in PHA-induced PBMC proliferation after injections of MSCs and the increase in the percentages of B lymphocytes support the involvement of MSCs in immune-mediated processes. The data from this work also showed that intravenous administration was well-tolerated: no serious adverse events were reported in the child. Therefore, the intravenous route of administration, taking advantage of the pulmonary first-pass effect that characterizes MSCs, could represent the optimal route of administration in lung diseases' treatment. In conclusion, this clinical study supports the use of serial infusions of MSCs in the pediatric treatment of mutated FLNA-associated respiratory failure [11].

In all studies, treatment with MSCs was authorized after receiving informed parental consent of enrolled children. The clinical trials (phases I/II) described above (Table 5) aim to show the safety and/or efficacy of MSC use as a therapeutic tool in pediatric BPD and chronic respiratory failure. 


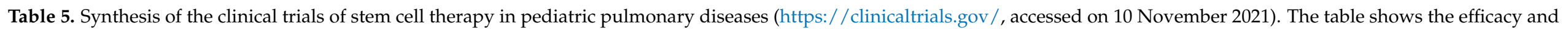
safety of stem cell therapy in the management of BPD and mutated FLNA-associated respiratory failure.

\begin{tabular}{|c|c|c|c|c|c|c|c|c|}
\hline Identifier & Phase & Subjects & Cells Therapy & $\begin{array}{c}\text { Route of } \\
\text { Administration }\end{array}$ & $\begin{array}{l}\text { Intervention/ } \\
\text { Treatment }\end{array}$ & Efficacy & Security & Ref. \\
\hline NCT01297205 & $\begin{array}{c}\text { Phase } 1 \\
\text { (completed) }\end{array}$ & $\begin{array}{l}9 \text { premature infants } \\
\text { (up to } 14 \text { days) at high } \\
\text { risk for BPD }\end{array}$ & $\begin{array}{c}\text { hUCB-MSCs } \\
\text { transplantation } \\
\text { (PNEUMOSTEM) }\end{array}$ & $\begin{array}{l}\text { Intratracheal } \\
\text { delivery }\end{array}$ & $\begin{array}{c}1 \times 10^{7} \text { or } \\
2 \times 10^{7} \text { cells } / \mathrm{kg}\end{array}$ & $\begin{array}{l}\text { Improvement of the } \\
\text { respiratory condition } \\
\text { Reduction of IL-1, } \\
\text { IL-6, IL-8, IL-10, } \\
\text { MMP-9, TGF- } \beta \text {, and } \\
\text { TNF- } \alpha \text { levels, in } \\
\text { tracheal aspirates }\end{array}$ & $\begin{array}{l}\text { Well-tolerated and } \\
\text { no serious adverse } \\
\text { events }\end{array}$ & [160] \\
\hline NCT02023788 & $\begin{array}{c}\text { Phase } 1 \\
\text { (completed) }\end{array}$ & $\begin{array}{l}8 \text { premature infants } \\
\text { (from } 45 \text { to } 63 \text { months) } \\
\text { at high risk for BPD }\end{array}$ & $\begin{array}{c}\text { hUCB-MSCs } \\
\text { transplantation } \\
\text { (PNEUMOSTEM) }\end{array}$ & $\begin{array}{l}\text { Intratracheal } \\
\text { delivery }\end{array}$ & $\begin{array}{c}1 \times 10^{7} \text { or } \\
2 \times 10^{7} \text { cells } / \mathrm{kg}\end{array}$ & - & - & - \\
\hline NCT01828957 & $\begin{array}{c}\text { Phase } 2 \\
\text { (completed) }\end{array}$ & $\begin{array}{l}69 \text { premature infants } \\
\text { (up to } 14 \text { days) at high } \\
\text { risk for BPD }\end{array}$ & $\begin{array}{c}\text { hUCB-MSCs } \\
\text { transplantation } \\
\text { (PNEUMOSTEM) }\end{array}$ & $\begin{array}{l}\text { Intratracheal } \\
\text { delivery }\end{array}$ & $1 \times 10^{7}$ cells $/ \mathrm{kg}$ & $\begin{array}{l}\text { Decrease of the IL- } 1 \beta \text {, } \\
\text { IL-6, IL- } 8, \text { TNF- } \alpha \text {, and } \\
\text { MMP-9 levels. } \\
\text { Improvement of the } \\
\text { outcome of severe } \\
\text { BPD }\end{array}$ & No adverse events & [162] \\
\hline NCT03392467 & $\begin{array}{c}\text { Phase } 2 \\
\text { (recruiting) }\end{array}$ & $\begin{array}{l}60 \text { premature infants } \\
\text { (up to } 13 \text { days) with } \\
\text { severe BPD }\end{array}$ & $\begin{array}{c}\text { hUCB-MSCs } \\
\text { transplantation } \\
\text { (PNEUMOSTEM) }\end{array}$ & $\begin{array}{l}\text { Intratracheal } \\
\text { delivery }\end{array}$ & $1 \times 10^{7}$ cells $/ \mathrm{kg}$ & - & - & - \\
\hline NCT01897987 & $\begin{array}{c}\text { Phase } 2 \\
\text { (completed) }\end{array}$ & $\begin{array}{l}62 \text { premature infants } \\
\text { at high risk for BPD }\end{array}$ & $\begin{array}{c}\text { hUCB-MSCs } \\
\text { transplantation } \\
\text { (PNEUMOSTEM) }\end{array}$ & $\begin{array}{l}\text { Intratracheal } \\
\text { delivery }\end{array}$ & $1 \times 10^{7}$ cells $/ \mathrm{kg}$ & - & - & - \\
\hline NCT02381366 & $\begin{array}{l}\text { Phase 1/2 } \\
\text { (completed) }\end{array}$ & $\begin{array}{l}9 \text { premature infants } \\
\text { (up to } 14 \text { days) at high } \\
\text { risk for BPD }\end{array}$ & $\begin{array}{c}\text { hUCB-MSCs } \\
\text { transplantation } \\
\text { (PNEUMOSTEM) }\end{array}$ & $\begin{array}{l}\text { Intratracheal } \\
\text { delivery }\end{array}$ & $\begin{array}{c}1 \times 10^{7} \text { or } \\
2 \times 10^{7} \text { cells } / \mathrm{kg}\end{array}$ & - & $\begin{array}{l}\text { Well-tolerated } \\
\text { without signs of } \\
\text { toxicity } \\
\text { No serious } \\
\text { adverse events }\end{array}$ & [163] \\
\hline
\end{tabular}


Table 5. Cont.

\begin{tabular}{|c|c|c|c|c|c|c|c|c|}
\hline Identifier & Phase & Subjects & Cells Therapy & $\begin{array}{c}\text { Route of } \\
\text { Administration }\end{array}$ & $\begin{array}{l}\text { Intervention/ } \\
\text { Treatment }\end{array}$ & Efficacy & Security & Ref. \\
\hline NCT03601416 & $\begin{array}{c}\text { Phase } 1 \\
\text { (not yet recruiting) }\end{array}$ & $\begin{array}{l}72 \text { children (up to } \\
1 \text { year) with moderate } \\
\text { and severe BPD }\end{array}$ & $\begin{array}{c}\text { Allogenic } \\
\text { hUC-MSCs } \\
\text { transplantation }\end{array}$ & $\begin{array}{l}\text { Intravenous } \\
\text { administration }\end{array}$ & $\begin{array}{c}2.5 \times 10^{6} \text { or } \\
5 \times 10^{6} \text { cells } / \mathrm{kg}\end{array}$ & - & - & [9] \\
\hline NCT02443961 & $\begin{array}{l}\text { Phase } 1 \\
\text { (active, not } \\
\text { recruiting) }\end{array}$ & $\begin{array}{l}10 \text { preterm newborns } \\
\text { (from } 1 \text { month to } \\
28 \text { weeks) at high risk } \\
\text { of BPD }\end{array}$ & $\begin{array}{c}\text { MSCs } \\
\text { transplantation }\end{array}$ & - & $\begin{array}{c}3 \text { doses of } \\
5 \times 10^{6} \text { cells } / \mathrm{kg}\end{array}$ & - & - & - \\
\hline NCT03631420 & $\begin{array}{l}\text { Phase } 1 \\
\text { (active, not } \\
\text { recruiting) }\end{array}$ & $\begin{array}{c}9 \text { infants (up to } \\
51 \text { days) at high risk } \\
\text { for BPD }\end{array}$ & $\begin{array}{l}\text { hUC-MSCs } \\
\text { transplantation }\end{array}$ & - & $\begin{array}{l}3 \times 10^{6}, \text { or } 10 \times 10^{6} \\
\text { or } 30 \times 10^{6} \text { cells } / \mathrm{kg}\end{array}$ & - & - & - \\
\hline NCT01207869 & $\begin{array}{l}\text { Phase } 1 \text { (active, } \\
\text { not recruiting) }\end{array}$ & $\begin{array}{l}9 \text { extremely premature } \\
\text { infants (up to } \\
6 \text { months) with severe } \\
\text { BPD }\end{array}$ & $\begin{array}{l}\text { hUC-MSCs } \\
\text { transplantation }\end{array}$ & $\begin{array}{l}\text { Intratracheal } \\
\text { delivery }\end{array}$ & $3 \times 10^{6}$ cells $/ \mathrm{kg}$ & - & - & - \\
\hline NCT04255147 & $\begin{array}{l}\text { Phase } 1 \text { (not yet } \\
\text { recruiting) }\end{array}$ & $\begin{array}{c}9 \text { extremely premature } \\
\text { infants (up to } 21 \text { days) } \\
\text { at risk of BPD }\end{array}$ & $\begin{array}{c}\text { Allogeneic } \\
\text { UC-MSCs } \\
\text { transplantation }\end{array}$ & $\begin{array}{l}\text { Intravenous } \\
\text { administration }\end{array}$ & $\begin{array}{l}1 \times 10^{6}, \text { or } 3 \times 10^{6} \\
\text { or } 10 \times 10^{6} \text { cells } / \mathrm{kg}\end{array}$ & - & - & - \\
\hline NCT03683953 & $\begin{array}{l}\text { Phase } 1 \text { (not yet } \\
\text { recruiting) }\end{array}$ & $\begin{array}{c}200 \text { infants } \\
\text { (28-37 weeks) with } \\
\text { BPD }\end{array}$ & $\begin{array}{c}\text { MSCs } \\
\text { transplantation }\end{array}$ & $\begin{array}{c}\text { Intratracheal } \\
\text { delivery }\end{array}$ & $\begin{array}{l}25 \times 10^{6} \text { cells } / \mathrm{kg} \text {, } \\
\text { administrated on } \\
14 \text { days after birth }\end{array}$ & - & - & - \\
\hline NCT03774537 & $\begin{array}{l}\text { Phase } 1 / 2 \\
\text { (recruiting) }\end{array}$ & $\begin{array}{l}20 \text { preterm infants (up } \\
\text { to } 14 \text { days) at high risk } \\
\text { for BPD }\end{array}$ & $\begin{array}{l}\text { hUC-MSCs } \\
\text { transplantation }\end{array}$ & $\begin{array}{c}\text { Intravenous } \\
\text { administration }\end{array}$ & $\begin{array}{c}1 \times 10^{6} \text { or } 5 \times 10^{6} \\
\text { cells } / \mathrm{kg}\end{array}$ & - & - & - \\
\hline NCT03558334 & $\begin{array}{l}\text { Phase } 1 / 2 \\
\text { (recruiting) }\end{array}$ & $\begin{array}{l}12 \text { premature infants } \\
\text { with moderate and } \\
\text { severe BPD }\end{array}$ & $\begin{array}{l}\text { hUC-MSCs } \\
\text { transplantation }\end{array}$ & $\begin{array}{c}\text { Intravenous } \\
\text { administration }\end{array}$ & $\begin{array}{c}1 \times 10^{6} \text { or } \\
5 \times 10^{6} \text { cells } / \mathrm{kg}\end{array}$ & - & - & - \\
\hline NCT03873506 & $\begin{array}{c}\text { Phase } 1 \\
\text { (recruiting) }\end{array}$ & $\begin{array}{l}30 \text { premature infants } \\
\text { (from } 1 \text { month to } \\
5 \text { years) with } \\
\text { moderate and severe } \\
\text { BPD }\end{array}$ & $\begin{array}{l}\text { hUC-MSCs } \\
\text { transplantation }\end{array}$ & $\begin{array}{l}\text { Intravenous } \\
\text { administration }\end{array}$ & $\begin{array}{c}1 \times 10^{6} \text { or } \\
5 \times 10^{6} \text { cells } / \mathrm{kg}\end{array}$ & - & - & - \\
\hline
\end{tabular}


Table 5. Cont

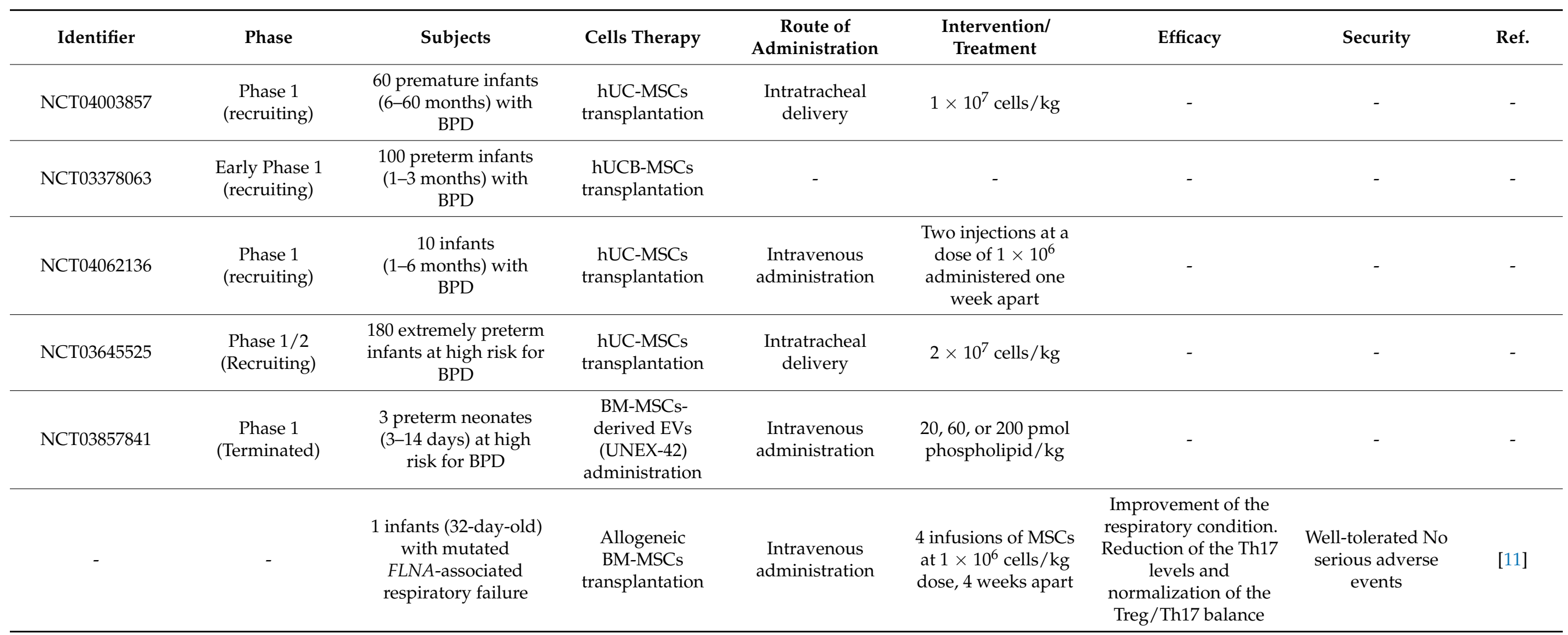

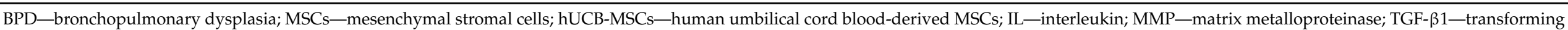

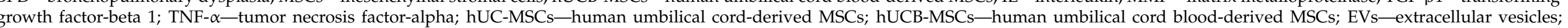
FLNA-filamin A. 


\section{Future Perspectives}

Repetitive micro injury to the AEC, which leads to aberrant repair during tissue regeneration, is a central paradigm of chILD [95]. Currently medical treatment of chILD is empirical with varying efficacy. Prospective therapies must be developed to ameliorate the prognosis of chILD. MSCs may be considered a promising cellular source to prevent disease progression or to revert established lung fibrosis, suppressing inflammation and supporting alveolar repair. The role of MSCs in the reparative and regenerative processes can also be considered. The plasticity of fibrosis [102] in the pediatric context of pulmonary disorders associated with fibrosis might represent an additional opportunity for cell therapy. A multidisciplinary team approach represents the standard of care for chILD diagnosis and management; it should become a core standard in post-operative treatment of cystic lesions and pneumothorax relapses in chronic pediatric lung disease. Combined treatment including medicaments, cell therapy, and surgery could offer a novel therapeutic approach in children, even in case of severe lung hypoplasia related to complex congenital malformations such as pulmonary malformations, congenital diaphragmatic hernia, or lung volume resection in FLNA gene mutations. The poor prognosis when prenatally diagnosed could be mitigated from birth by the use of combined therapy including surgery and stem cells with the aim of promoting lung growth.

\section{Conclusions}

Cellular therapy represents a potential treatment for chILD. Even though beneficial effects have been reported in clinical and preclinical studies, the optimal dosage, cell type, cell source, and route of administration have not yet been fully elucidated. Due to their tissue-regenerative and immunomodulatory properties, MSCs combined with other therapy or alone could be considered an innovative approach for the repair and regeneration of the lung during disease progression and/or as post-surgical lung support after pulmonary resection due to severe respiratory complications in chronic lung diseases.

Author Contributions: Conceptualization, G.P., E.M. and V.C.; methodology, G.P., S.S., M.A.A., G.Z., E.M. and V.C.; investigation, S.S., M.A.A. and V.C.; resources, G.P. and E.M.; writing-original draft preparation, G.P., S.S., M.A.A., G.Z., E.M. and V.C.; writing-review and editing, G.P., S.S., M.A.A., G.Z., E.M. and V.C.; supervision, G.P., E.M., G.Z. and V.C. All authors have read and agreed to the published version of the manuscript.

Funding: This research is a part of the project that was funded by Fondo Integrativo Speciale per la Ricerca Covid-19, Ministero dell’Università e della Ricerca, FISR2020IP_02959.

Institutional Review Board Statement: Not applicable.

Informed Consent Statement: Not applicable.

Data Availability Statement: Not applicable.

Conflicts of Interest: The authors declare no conflict of interest.

\section{References}

1. Samarelli, A.V.; Tonelli, R.; Marchioni, A.; Bruzzi, G.; Gozzi, F.; Andrisani, D.; Castaniere, I.; Manicardi, L.; Moretti, A.; Tabbi, L.; et al. Fibrotic idiopathic interstitial lung disease: The molecular and cellular key players. Int. J. Mol. Sci. 2021, 22, 8952. [CrossRef]

2. Brennan, L.C.; O'Sullivan, A.; MacLoughlin, R. Cellular therapy for the treatment of paediatric respiratory disease. Int. J. Mol. Sci. 2021, 22, 8906. [CrossRef] [PubMed]

3. Tong, Y.; Zuo, J.; Yue, D. Application prospects of mesenchymal stem cell therapy for bronchopulmonary dysplasia and the challenges encountered. BioMed Res. Int. 2021, 2021, 9983664. [CrossRef]

4. Chia, W.K.; Cheah, F.C.; Abdul Aziz, N.H.; Kampan, N.C.; Shuib, S.; Khong, T.Y.; Tan, G.C.; Wong, Y.P. A review of placenta and umbilical cord-derived stem cells and the immunomodulatory basis of their therapeutic potential in bronchopulmonary dysplasia. Front. Pediatr. 2021, 9, 615508. [CrossRef] [PubMed]

5. Hashemian, S.R.; Aliannejad, R.; Zarrabi, M.; Soleimani, M.; Vosough, M.; Hosseini, S.E.; Hossieni, H.; Keshel, S.H.; Naderpour, Z.; Hajizadeh-Saffar, E.; et al. Mesenchymal stem cells derived from perinatal tissues for treatment of critically ill covid-19-induced ards patients: A case series. Stem Cell Res. Ther. 2021, 12, 91. [CrossRef] 
6. Oktem, A.; Celik, H.T.; Yigit, S.; Yurdakok, M. The clinical and radiological course of bronchopulmonary dysplasia in twins treated with mesenchymal stem cells and followed up using lung ultrasonography. Turk Pediatr. Ars. 2020, 55, 425-429.

7. Guo, H.; Su, Y.; Deng, F. Effects of mesenchymal stromal cell-derived extracellular vesicles in lung diseases: Current status and future perspectives. Stem Cell Rev. Rep. 2021, 17, 440-458. [CrossRef] [PubMed]

8. Sahni, M.; Bhandari, V. Recent advances in understanding and management of bronchopulmonary dysplasia. F1000Research 2020, 9, 703. [CrossRef]

9. Wu, X.; Xia, Y.; Zhou, O.; Song, Y.; Zhang, X.; Tian, D.; Li, Q.; Shu, C.; Liu, E.; Yuan, X.; et al. Allogeneic human umbilical cord-derived mesenchymal stem cells for severe bronchopulmonary dysplasia in children: Study protocol for a randomized controlled trial (msc-bpd trial). Trials 2020, 21, 125. [CrossRef]

10. Yonker, L.M.; Hawley, M.H.; Kinane, T.B. Do mesenchymal stromal cell infusions advance the understanding and treatment options of flna-associated pulmonary disease? Pediatr. Pulmonol. 2020, 55, 270-271. [CrossRef]

11. Pelizzo, G.; Avanzini, M.A.; Lenta, E.; Mantelli, M.; Croce, S.; Catenacci, L.; Acquafredda, G.; Ferraro, A.L.; Giambanco, C.; D'Amelio, L.; et al. Allogeneic mesenchymal stromal cells: Novel therapeutic option for mutated flna-associated respiratory failure in the pediatric setting. Pediatr. Pulmonol. 2020, 55, 190-197. [CrossRef]

12. Eggenhofer, E.; Luk, F.; Dahlke, M.H.; Hoogduijn, M.J. The life and fate of mesenchymal stem cells. Front. Immunol. 2014, 5, 148. [CrossRef]

13. Hass, R.; Kasper, C.; Bohm, S.; Jacobs, R. Different populations and sources of human mesenchymal stem cells (msc): A comparison of adult and neonatal tissue-derived msc. Cell Commun. Signal. CCS 2011, 9, 12. [CrossRef] [PubMed]

14. Mobius, M.A.; Rudiger, M. Mesenchymal stromal cells in the development and therapy of bronchopulmonary dysplasia. Mol. Cell. Pediatr. 2016, 3, 18. [CrossRef] [PubMed]

15. Sinclair, K.; Yerkovich, S.T.; Chambers, D.C. Mesenchymal stem cells and the lung. Respirology 2013, 18, 397-411. [CrossRef]

16. Hogan, B.L.; Yingling, J.M. Epithelial/mesenchymal interactions and branching morphogenesis of the lung. Curr. Opin. Genet. Dev. 1998, 8, 481-486. [CrossRef]

17. Nathan, N.; Berdah, L.; Delestrain, C.; Sileo, C.; Clement, A. Interstitial lung diseases in children. Presse Med. 2020, 49, 103909. [CrossRef] [PubMed]

18. Clement, A.; Nathan, N.; Epaud, R.; Fauroux, B.; Corvol, H. Interstitial lung diseases in children. Orphanet J. Rare Dis. 2010, 5, 22. [CrossRef]

19. Langer, F.; Werlein, C.; Soudah, B.; Schwerk, N.; Jonigk, D. Interstitial lung disease in infancy and early childhood. Pathologe 2021, $42,25-34$.

20. Deutsch, G.H.; Young, L.R.; Deterding, R.R.; Fan, L.L.; Dell, S.D.; Bean, J.A.; Brody, A.S.; Nogee, L.M.; Trapnell, B.C.; Langston, C.; et al. Diffuse lung disease in young children: Application of a novel classification scheme. Am. J. Respir. Crit. Care Med. 2007, 176, 1120-1128. [CrossRef]

21. Li, D.Y.; Li, R.F.; Sun, D.X.; Pu, D.D.; Zhang, Y.H. Mesenchymal stem cell therapy in pulmonary fibrosis: A meta-analysis of preclinical studies. Stem Cell Res. Ther. 2021, 12, 461. [CrossRef]

22. Huang, Y.; Yang, L. Mesenchymal stem cell-derived extracellular vesicles in therapy against fibrotic diseases. Stem Cell Res. Ther. 2021, 12, 435. [CrossRef]

23. Chen, Y.T.; Miao, K.; Zhou, L.; Xiong, W.N. Stem cell therapy for chronic obstructive pulmonary disease. Chin. Med. J. 2021, 134, 1535-1545. [CrossRef]

24. Su, Y.; Guo, H.; Liu, Q. Effects of mesenchymal stromal cell-derived extracellular vesicles in acute respiratory distress syndrome (ards): Current understanding and future perspectives. J. Leukoc. Biol. 2021, 110, 27-38. [CrossRef]

25. Glassberg, M.K.; Csete, I.; Simonet, E.; Elliot, S.J. Stem cell therapy for copd: Hope and exploitation. Chest 2021, 160, 1271-1281. [CrossRef] [PubMed]

26. Yang, S.; Liu, P.; Jiang, Y.; Wang, Z.; Dai, H.; Wang, C. Therapeutic applications of mesenchymal stem cells in idiopathic pulmonary fibrosis. Front. Cell Dev. Biol. 2021, 9, 639657. [CrossRef] [PubMed]

27. Niu, S.; Zhang, Y. Applications and therapeutic mechanisms of action of mesenchymal stem cells in radiation-induced lung injury. Stem Cell Res. Ther. 2021, 12, 212.

28. Goetz, M.J.; Kremer, S.; Behnke, J.; Staude, B.; Shahzad, T.; Holzfurtner, L.; Chao, C.M.; Morty, R.E.; Bellusci, S.; Ehrhardt, H. Msc based therapies to prevent or treat bpd-a narrative review on advances and ongoing challenges. Int. J. Mol. Sci. 2021, 22, 1138. [CrossRef] [PubMed]

29. Ali, K.M.; Fattah, F.H.R.; Omar, S.H.; Gubari, M.I.M.; Yousefifard, M.; Hosseini, M. Mesenchymal stromal cells derived conditioned medium in pulmonary fibrosis: A systematic review and meta-analysis. Arch. Iran. Med. 2020, 23, 870-879. [CrossRef]

30. Chuang, H.M.; Shih, T.E.; Lu, K.Y.; Tsai, S.F.; Harn, H.J.; Ho, L.I. Mesenchymal stem cell therapy of pulmonary fibrosis: Improvement with target combination. Cell Transplant. 2018, 27, 1581-1587. [CrossRef]

31. Broekman, W.; Khedoe, P.; Schepers, K.; Roelofs, H.; Stolk, J.; Hiemstra, P.S. Mesenchymal stromal cells: A novel therapy for the treatment of chronic obstructive pulmonary disease? Thorax 2018, 73, 565-574. [CrossRef] [PubMed]

32. Vizoso, F.J.; Eiro, N.; Cid, S.; Schneider, J.; Perez-Fernandez, R. Mesenchymal stem cell secretome: Toward cell-free therapeutic strategies in regenerative medicine. Int. J. Mol. Sci. 2017, 18, 1852. [CrossRef] [PubMed]

33. Eleuteri, S.; Fierabracci, A. Insights into the secretome of mesenchymal stem cells and its potential applications. Int. J. Mol. Sci. 2019, 20, 4597. [CrossRef] 
34. Harrell, C.R.; Fellabaum, C.; Jovicic, N.; Djonov, V.; Arsenijevic, N.; Volarevic, V. Molecular mechanisms responsible for therapeutic potential of mesenchymal stem cell-derived secretome. Cells 2019, 8, 467. [CrossRef]

35. Pierro, M.; Ciarmoli, E.; Thebaud, B. Bronchopulmonary dysplasia and chronic lung disease: Stem cell therapy. Clin. Perinatol. 2015, 42, 889-910. [CrossRef] [PubMed]

36. Van Haaften, T.; Byrne, R.; Bonnet, S.; Rochefort, G.Y.; Akabutu, J.; Bouchentouf, M.; Rey-Parra, G.J.; Galipeau, J.; Haromy, A.; Eaton, F.; et al. Airway delivery of mesenchymal stem cells prevents arrested alveolar growth in neonatal lung injury in rats. Am. J. Respir. Crit. Care Med. 2009, 180, 1131-1142. [CrossRef]

37. Dennis, J.E.; Caplan, A.I. Advances in mesenchymal stem cell biology. Curr. Opin. Orthop. 2004, 15, 341-346. [CrossRef]

38. Kallmeyer, K.; Pepper, M.S. Homing properties of mesenchymal stromal cells. Expert Opin. Biol. Ther. 2015, 15, 477-479. [CrossRef]

39. Le Blanc, K.; Mougiakakos, D. Multipotent mesenchymal stromal cells and the innate immune system. Nat. Rev. Immunol. 2012, 12, 383-396. [CrossRef]

40. Horwitz, E.M.; Le Blanc, K.; Dominici, M.; Mueller, I.; Slaper-Cortenbach, I.; Marini, F.C.; Deans, R.J.; Krause, D.S.; Keating, A. Clarification of the nomenclature for msc: The international society for cellular therapy position statement. Cytotherapy 2005, 7, 393-395. [CrossRef] [PubMed]

41. Dominici, M.; Le Blanc, K.; Mueller, I.; Slaper-Cortenbach, I.; Marini, F.; Krause, D.; Deans, R.; Keating, A.; Prockop, D.; Horwitz, E. Minimal criteria for defining multipotent mesenchymal stromal cells. The international society for cellular therapy position statement. Cytotherapy 2006, 8, 315-317. [CrossRef]

42. Barzilay, R.; Melamed, E.; Offen, D. Introducing transcription factors to multipotent mesenchymal stem cells: Making transdifferentiation possible. Stem Cells 2009, 27, 2509-2515. [CrossRef]

43. Sabatini, F.; Petecchia, L.; Tavian, M.; Jodon de Villeroche, V.; Rossi, G.A.; Brouty-Boye, D. Human bronchial fibroblasts exhibit a mesenchymal stem cell phenotype and multilineage differentiating potentialities. Lab. Investig. J. Tech. Methods Pathol. 2005, 85, 962-971. [CrossRef] [PubMed]

44. Yagi, H.; Soto-Gutierrez, A.; Parekkadan, B.; Kitagawa, Y.; Tompkins, R.G.; Kobayashi, N.; Yarmush, M.L. Mesenchymal stem cells: Mechanisms of immunomodulation and homing. Cell Transplant. 2010, 19, 667-679. [CrossRef] [PubMed]

45. Zhao, Q.; Ren, H.; Han, Z. Mesenchymal stem cells: Immunomodulatory capability and clinical potential in immune diseases. J. Cell. Immunother. 2016, 2, 3-20. [CrossRef]

46. Wecht, S.; Rojas, M. Mesenchymal stem cells in the treatment of chronic lung disease. Respirology 2016, 21, 1366-1375. [CrossRef]

47. Inamdar, A.C.; Inamdar, A.A. Mesenchymal stem cell therapy in lung disorders: Pathogenesis of lung diseases and mechanism of action of mesenchymal stem cell. Exp. Lung Res. 2013, 39, 315-327. [CrossRef]

48. Rojas, M.; Xu, J.; Woods, C.R.; Mora, A.L.; Spears, W.; Roman, J.; Brigham, K.L. Bone marrow-derived mesenchymal stem cells in repair of the injured lung. Am. J. Respir. Cell Mol. Biol. 2005, 33, 145-152. [CrossRef]

49. Sueblinvong, V.; Loi, R.; Eisenhauer, P.L.; Bernstein, I.M.; Suratt, B.T.; Spees, J.L.; Weiss, D.J. Derivation of lung epithelium from human cord blood-derived mesenchymal stem cells. Am. J. Respir. Crit. Care Med. 2008, 177, 701-711. [CrossRef] [PubMed]

50. Liu, A.R.; Liu, L.; Chen, S.; Yang, Y.; Zhao, H.J.; Liu, L.; Guo, F.M.; Lu, X.M.; Qiu, H.B. Activation of canonical wnt pathway promotes differentiation of mouse bone marrow-derived mscs into type ii alveolar epithelial cells, confers resistance to oxidative stress, and promotes their migration to injured lung tissue in vitro. J. Cell. Physiol. 2013, 228, 1270-1283. [CrossRef]

51. Loi, R.; Beckett, T.; Goncz, K.K.; Suratt, B.T.; Weiss, D.J. Limited restoration of cystic fibrosis lung epithelium In Vivo with adult bone marrow-derived cells. Am. J. Respir. Crit. Care Med. 2006, 173, 171-179. [CrossRef] [PubMed]

52. Weiss, D.J.; Casaburi, R.; Flannery, R.; LeRoux-Williams, M.; Tashkin, D.P. A placebo-controlled, randomized trial of mesenchymal stem cells in copd. Chest 2013, 143, 1590-1598. [CrossRef] [PubMed]

53. Zhang, P.; Yeo, J.C.; Lim, C.T. Advances in technologies for purification and enrichment of extracellular vesicles. SLAS Technol. 2019, 24, 477-488. [CrossRef]

54. Camussi, G.; Deregibus, M.C.; Bruno, S.; Grange, C.; Fonsato, V.; Tetta, C. Exosome/microvesicle-mediated epigenetic reprogramming of cells. Am. J. Cancer Res. 2011, 1, 98-110. [PubMed]

55. Valadi, H.; Ekstrom, K.; Bossios, A.; Sjostrand, M.; Lee, J.J.; Lotvall, J.O. Exosome-mediated transfer of mrnas and micrornas is a novel mechanism of genetic exchange between cells. Nat. Cell Biol. 2007, 9, U654-U672. [CrossRef]

56. Fierabracci, A.; Del Fattore, A.; Muraca, M. The immunoregulatory activity of mesenchymal stem cells: 'State of art' and 'future avenues'. Curr. Med. Chem. 2016, 23, 3014-3024. [CrossRef]

57. Turturici, G.; Tinnirello, R.; Sconzo, G.; Geraci, F. Extracellular membrane vesicles as a mechanism of cell-to-cell communication: Advantages and disadvantages. Am. J. Physiol. Cell Physiol. 2014, 306, C621-C633. [CrossRef]

58. Camussi, G.; Deregibus, M.C.; Bruno, S.; Cantaluppi, V.; Biancone, L. Exosomes/microvesicles as a mechanism of cell-to-cell communication. Kidney Int. 2010, 78, 838-848. [CrossRef]

59. Samanta, S.; Rajasingh, S.; Drosos, N.; Zhou, Z.; Dawn, B.; Rajasingh, J. Exosomes: New molecular targets of diseases. Acta Pharmacol. Sin. 2018, 39, 501-513. [CrossRef]

60. Kowal, E.J.K.; Ter-Ovanesyan, D.; Regev, A.; Church, G.M. Extracellular vesicle isolation and analysis by western blotting. Methods Mol. Biol. 2017, 1660, 143-152. [PubMed]

61. Subedi, P.; Schneider, M.; Philipp, J.; Azimzadeh, O.; Metzger, F.; Moertl, S.; Atkinson, M.J.; Tapio, S. Comparison of methods to isolate proteins from extracellular vesicles for mass spectrometry-based proteomic analyses. Anal. Biochem. 2019, 584, 113390. [CrossRef] 
62. Kalra, H.; Drummen, G.P.; Mathivanan, S. Focus on extracellular vesicles: Introducing the next small big thing. Int. J. Mol. Sci. 2016, 17, 170. [CrossRef]

63. Mardpour, S.; Hamidieh, A.A.; Taleahmad, S.; Sharifzad, F.; Taghikhani, A.; Baharvand, H. Interaction between mesenchymal stromal cell-derived extracellular vesicles and immune cells by distinct protein content. J. Cell. Physiol. 2019, 234, 8249-8258. [CrossRef]

64. McKelvey, K.J.; Powell, K.L.; Ashton, A.W.; Morris, J.M.; McCracken, S.A. Exosomes: Mechanisms of uptake. J. Circ. Biomark. 2015, 4, 7. [CrossRef]

65. Ragni, E.; Banfi, F.; Barilani, M.; Cherubini, A.; Parazzi, V.; Larghi, P.; Dolo, V.; Bollati, V.; Lazzari, L. Extracellular vesicle-shuttled mrna in mesenchymal stem cell communication. Stem Cells 2017, 35, 1093-1105. [CrossRef]

66. Lai, R.C.; Yeo, R.W.; Lim, S.K. Mesenchymal stem cell exosomes. Semin. Cell Dev. Biol. 2015, 40, 82-88. [CrossRef]

67. Fierabracci, A.; Del Fattore, A.; Luciano, R.; Muraca, M.; Teti, A.; Muraca, M. Recent advances in mesenchymal stem cell immunomodulation: The role of microvesicles. Cell Transplant. 2015, 24, 133-149. [CrossRef] [PubMed]

68. Silvestro, S.; Chiricosta, L.; Gugliandolo, A.; Pizzicannella, J.; Diomede, F.; Bramanti, P.; Trubiani, O.; Mazzon, E. Extracellular vesicles derived from human gingival mesenchymal stem cells: A transcriptomic analysis. Genes 2020, 11, 118. [CrossRef]

69. Gowen, A.; Shahjin, F.; Chand, S.; Odegaard, K.E.; Yelamanchili, S.V. Mesenchymal stem cell-derived extracellular vesicles: Challenges in clinical applications. Front. Cell Dev. Biol. 2020, 8, 149. [CrossRef] [PubMed]

70. Joseph, A.; Baiju, I.; Bhat, I.A.; Pandey, S.; Bharti, M.; Verma, M.; Pratap Singh, A.; Ansari, M.M.; Chandra, V.; Saikumar, G.; et al. Mesenchymal stem cell-conditioned media: A novel alternative of stem cell therapy for quality wound healing. J. Cell. Physiol. 2020, 235, 5555-5569. [CrossRef] [PubMed]

71. Moreira, A.; Naqvi, R.; Hall, K.; Emukah, C.; Martinez, J.; Moreira, A.; Dittmar, E.; Zoretic, S.; Evans, M.; Moses, D.; et al. Effects of mesenchymal stromal cell-conditioned media on measures of lung structure and function: A systematic review and meta-analysis of preclinical studies. Stem Cell Res. Ther. 2020, 11, 399. [CrossRef] [PubMed]

72. Kawamura, R.; Hayashi, Y.; Murakami, H.; Nakashima, M. Edta soluble chemical components and the conditioned medium from mobilized dental pulp stem cells contain an inductive microenvironment, promoting cell proliferation, migration, and odontoblastic differentiation. Stem Cell Res. Ther. 2016, 7, 1-14. [CrossRef]

73. Murakami, M.; Hayashi, Y.; Iohara, K.; Osako, Y.; Hirose, Y.; Nakashima, M. Trophic effects and regenerative potential of mobilized mesenchymal stem cells from bone marrow and adipose tissue as alternative cell sources for pulp/dentin regeneration. Cell Transplant. 2015, 24, 1753-1765. [CrossRef] [PubMed]

74. Kichenbrand, C.; Velot, E.; Menu, P.; Moby, V. Dental pulp stem cell-derived conditioned medium: An attractive alternative for regenerative therapy. Tissue Eng. Part B Rev. 2019, 25, 78-88. [CrossRef]

75. Sagaradze, G.; Grigorieva, O.; Nimiritsky, P.; Basalova, N.; Kalinina, N.; Akopyan, Z.; Efimenko, A. Conditioned medium from human mesenchymal stromal cells: Towards the clinical translation. Int. J. Mol. Sci. 2019, 20, 1656. [CrossRef] [PubMed]

76. Osugi, M.; Katagiri, W.; Yoshimi, R.; Inukai, T.; Hibi, H.; Ueda, M. Conditioned media from mesenchymal stem cells enhanced bone regeneration in rat calvarial bone defects. Tissue Eng. Part A 2012, 18, 1479-1489. [CrossRef]

77. Katagiri, W.; Kawai, T.; Osugi, M.; Sugimura-Wakayama, Y.; Sakaguchi, K.; Kojima, T.; Kobayashi, T. Angiogenesis in newly regenerated bone by secretomes of human mesenchymal stem cells. Maxillofac. Plast. Reconstr. Surg. 2017, 39, 8. [CrossRef]

78. Kawai, T.; Katagiri, W.; Osugi, M.; Sugimura, Y.; Hibi, H.; Ueda, M. Secretomes from bone marrow-derived mesenchymal stromal cells enhance periodontal tissue regeneration. Cytotherapy 2015, 17, 369-381. [CrossRef]

79. Ionescu, L.; Byrne, R.N.; van Haaften, T.; Vadivel, A.; Alphonse, R.S.; Rey-Parra, G.J.; Weissmann, G.; Hall, A.; Eaton, F.; Thebaud, B. Stem cell conditioned medium improves acute lung injury in mice: In Vivo evidence for stem cell paracrine action. Am. J. Physiol. Lung Cell. Mol. Physiol. 2012, 303, L967-L977. [CrossRef]

80. Rathinasabapathy, A.; Bruce, E.; Espejo, A.; Horowitz, A.; Sudhan, D.R.; Nair, A.; Guzzo, D.; Francis, J.; Raizada, M.K.; Shenoy, V.; et al. Therapeutic potential of adipose stem cell-derived conditioned medium against pulmonary hypertension and lung fibrosis. Br. J. Pharmacol. 2016, 173, 2859-2879. [CrossRef]

81. Kean, T.J.; Lin, P.; Caplan, A.I.; Dennis, J.E. Mscs: Delivery routes and engraftment, cell-targeting strategies, and immune modulation. Stem Cells Int. 2013, 2013, 732742. [CrossRef] [PubMed]

82. Fischer, U.M.; Harting, M.T.; Jimenez, F.; Monzon-Posadas, W.O.; Xue, H.; Savitz, S.I.; Laine, G.A.; Cox, C.S., Jr. Pulmonary passage is a major obstacle for intravenous stem cell delivery: The pulmonary first-pass effect. Stem Cells Dev. 2009, 18, 683-692. [CrossRef]

83. Gao, J.; Dennis, J.E.; Muzic, R.F.; Lundberg, M.; Caplan, A.I. The dynamic In Vivo distribution of bone marrow-derived mesenchymal stem cells after infusion. Cells Tissues Organs 2001, 169, 12-20. [CrossRef] [PubMed]

84. Schrepfer, S.; Deuse, T.; Reichenspurner, H.; Fischbein, M.P.; Robbins, R.C.; Pelletier, M.P. Stem cell transplantation: The lung barrier. Transplant. Proc. 2007, 39, 573-576. [CrossRef]

85. Durand, N.; Mallea, J.; Zubair, A.C. Insights into the use of mesenchymal stem cells in covid-19 mediated acute respiratory failure. NPJ Regen. Med. 2020, 5, 17. [CrossRef]

86. Li, X.; An, G.; Wang, Y.; Liang, D.; Zhu, Z.; Tian, L. Targeted migration of bone marrow mesenchymal stem cells inhibits silica-induced pulmonary fibrosis in rats. Stem Cell Res. Ther. 2018, 9, 335. [CrossRef] 
87. Lee, R.H.; Pulin, A.A.; Seo, M.J.; Kota, D.J.; Ylostalo, J.; Larson, B.L.; Semprun-Prieto, L.; Delafontaine, P.; Prockop, D.J. Intravenous hmscs improve myocardial infarction in mice because cells embolized in lung are activated to secrete the anti-inflammatory protein tsg-6. Cell Stem Cell 2009, 5, 54-63. [CrossRef]

88. Kim, J.; Guenthart, B.; O’Neill, J.D.; Dorrello, N.V.; Bacchetta, M.; Vunjak-Novakovic, G. Controlled delivery and minimally invasive imaging of stem cells in the lung. Sci. Rep. 2017, 7, 13082. [CrossRef]

89. Caplan, H.; Olson, S.D.; Kumar, A.; George, M.; Prabhakara, K.S.; Wenzel, P.; Bedi, S.; Toledano-Furman, N.E.; Triolo, F.; Kamhieh-Milz, J.; et al. Mesenchymal stromal cell therapeutic delivery: Translational challenges to clinical application. Front. Immunol. 2019, 10, 1645. [CrossRef] [PubMed]

90. Watanabe, M.; Yavagal, D.R. Intra-arterial delivery of mesenchymal stem cells. Brain Circ. 2016, 2, $114-117$.

91. Guzman, R.; Janowski, M.; Walczak, P. Intra-arterial delivery of cell therapies for stroke. Stroke 2018, 49, 1075-1082. [CrossRef] [PubMed]

92. Borghardt, J.M.; Kloft, C.; Sharma, A. Inhaled therapy in respiratory disease: The complex interplay of pulmonary kinetic processes. Can. Respir. J. 2018, 2018, 2732017. [CrossRef] [PubMed]

93. Lan, Y.W.; Choo, K.B.; Chen, C.M.; Hung, T.H.; Chen, Y.B.; Hsieh, C.H.; Kuo, H.P.; Chong, K.Y. Hypoxia-preconditioned mesenchymal stem cells attenuate bleomycin-induced pulmonary fibrosis. Stem Cell Res. Ther. 2015, 6, 97. [CrossRef] [PubMed]

94. Zhu, Y.G.; Feng, X.M.; Abbott, J.; Fang, X.H.; Hao, Q.; Monsel, A.; Qu, J.M.; Matthay, M.A.; Lee, J.W. Human mesenchymal stem cell microvesicles for treatment of escherichia coli endotoxin-induced acute lung injury in mice. Stem Cells 2014, 32, 116-125. [CrossRef]

95. Wuyts, W.A.; Agostini, C.; Antoniou, K.M.; Bouros, D.; Chambers, R.C.; Cottin, V.; Egan, J.J.; Lambrecht, B.N.; Lories, R.; Parfrey, H.; et al. The pathogenesis of pulmonary fibrosis: A moving target. Eur. Respir. J. 2013, 41, 1207-1218. [CrossRef]

96. Leung, J.; Cho, Y.; Lockey, R.F.; Kolliputi, N. The role of aging in idiopathic pulmonary fibrosis. Lung 2015, 193, 605-610. [CrossRef]

97. Rice, A.; Tran-Dang, M.A.; Bush, A.; Nicholson, A.G. Diffuse lung disease in infancy and childhood: Expanding the child classification. Histopathology 2013, 63, 743-755. [CrossRef]

98. Kurland, G.; Deterding, R.R.; Hagood, J.S.; Young, L.R.; Brody, A.S.; Castile, R.G.; Dell, S.; Fan, L.L.; Hamvas, A.; Hilman, B.C.; et al. An official american thoracic society clinical practice guideline: Classification, evaluation, and management of childhood interstitial lung disease in infancy. Am. J. Respir. Crit. Care Med. 2013, 188, 376-394. [CrossRef]

99. Griese, M.; Irnstetter, A.; Hengst, M.; Burmester, H.; Nagel, F.; Ripper, J.; Feilcke, M.; Pawlita, I.; Gothe, F.; Kappler, M.; et al. Categorizing diffuse parenchymal lung disease in children. Orphanet J. Rare Dis. 2015, 10, 122. [CrossRef]

100. Casey, A.M.; Deterding, R.R.; Young, L.R.; Fishman, M.P.; Fiorino, E.K.; Liptzin, D.R. Overview of the child research network: A roadmap for progress and success in defining rare diseases. Pediatr. Pulmonol. 2020, 55, 1819-1827. [CrossRef]

101. Bush, A.; Cunningham, S.; de Blic, J.; Barbato, A.; Clement, A.; Epaud, R.; Hengst, M.; Kiper, N.; Nicholson, A.G.; Wetzke, M.; et al. European protocols for the diagnosis and initial treatment of interstitial lung disease in children. Thorax 2015, 70, 1078-1084. [CrossRef]

102. Cunningham, S.; Jaffe, A.; Young, L.R. Children's interstitial and diffuse lung disease. Lancet Child Adolesc. 2019, 3 , 568-577. [CrossRef]

103. Clement, A.; de Blic, J.; Epaud, R.; Galeron, L.; Nathan, N.; Hadchouel, A.; Barbato, A.; Snijders, D.; Kiper, N.; Cunningham, S.; et al. Management of children with interstitial lung diseases: The difficult issue of acute exacerbations. Eur. Respir. J. 2016, 48, 1559-1563. [CrossRef]

104. Hime, N.J.; Zurynski, Y.; Fitzgerald, D.; Selvadurai, H.; Phu, A.; Deverell, M.; Elliott, E.J.; Jaffe, A. Childhood interstitial lung disease: A systematic review. Pediatr. Pulmonol. 2015, 50, 1383-1392. [CrossRef]

105. Clement, A.; Force, E.R.S.T. Task force on chronic interstitial lung disease in immunocompetent children. Eur. Respir. J. 2004, 24, 686-697. [CrossRef] [PubMed]

106. Fan, L.L.; Kozinetz, C.A. Factors influencing survival in children with chronic interstitial lung disease. Am. J. Respir. Crit. Care Med. 1997, 156, 939-942. [CrossRef] [PubMed]

107. Wu, M.; Sharma, P.G.; Rajderkar, D.A. Childhood interstitial lung disease: A case-based review of the imaging findings. Ann. Thorac. Med. 2021, 16, 64-72.

108. Copley, S.J.; Bush, A. Hrct of paediatric lung disease. Paediatr. Respir. Rev. 2000, 1, 141-147.

109. Klusmann, M.; Owens, C. Hrct in paediatric diffuse interstitial lung disease-a review for 2009. Pediatr. Radiol. 2009, 39 (Suppl. 3), 471-481. [CrossRef] [PubMed]

110. Vrielynck, S.; Mamou-Mani, T.; Emond, S.; Scheinmann, P.; Brunelle, F.; de Blic, J. Diagnostic value of high-resolution ct in the evaluation of chronic infiltrative lung disease in children. AJR. Am. J. Roentgenol. 2008, 191, 914-920. [CrossRef]

111. Dinwiddie, R.; Sharief, N.; Crawford, O. Idiopathic interstitial pneumonitis in children: A national survey in the United Kingdom and ireland. Pediatr. Pulmonol. 2002, 34, 23-29. [CrossRef]

112. Yeh, T.F.; Lin, Y.J.; Lin, H.C.; Huang, C.C.; Hsieh, W.S.; Lin, C.H.; Tsai, C.H. Outcomes at school age after postnatal dexamethasone therapy for lung disease of prematurity. N. Engl. J. Med. 2004, 350, 1304-1313. [CrossRef]

113. Osika, E.; Muller, M.H.; Boccon-Gibod, L.; Fauroux, B.; Sardet, A.; Grosskopf, C.; Couvreur, J.; Tournier, G.; Clement, A. Idiopathic pulmonary fibrosis in infants. Pediatr. Pulmonol. 1997, 23, 49-54. [CrossRef]

114. Hacking, D.; Smyth, R.; Shaw, N.; Kokia, G.; Carty, H.; Heaf, D. Idiopathic pulmonary fibrosis in infants: Good prognosis with conservative management. Arch. Dis. Child. 2000, 83, 152-157. [CrossRef] [PubMed] 
115. Eldridge, W.B.; Zhang, Q.; Faro, A.; Sweet, S.C.; Eghtesady, P.; Hamvas, A.; Cole, F.S.; Wambach, J.A. Outcomes of lung transplantation for infants and children with genetic disorders of surfactant metabolism. J. Pediatr. 2017, 184, 157-164.e152. [CrossRef] [PubMed]

116. Glasser, S.W.; Hagood, J.S.; Wong, S.; Taype, C.A.; Madala, S.K.; Hardie, W.D. Mechanisms of lung fibrosis resolution. Am. J. Pathol. 2016, 186, 1066-1077. [CrossRef]

117. Walters, D.M.; Kleeberger, S.R. Mouse models of bleomycin-induced pulmonary fibrosis. Curr. Protoc. Pharmacol. 2008, 5, 46. [CrossRef]

118. Moore, B.B.; Hogaboam, C.M. Murine models of pulmonary fibrosis. Am. J. Physiol. Lung Cell. Mol. Physiol. 2008, 294, L152-L160. [CrossRef]

119. Umezawa, H.; Ishizuka, M.; Maeda, K.; Takeuchi, T. Studies on bleomycin. Cancer 1967, 20, 891-895. [CrossRef]

120. Umezawa, H.; Maeda, K.; Takeuchi, T.; Okami, Y. New antibiotics, bleomycin a and b. J. Antibiot. 1966, 19, $200-209$.

121. Yagoda, A.; Mukherji, B.; Young, C.; Etcubanas, E.; Lamonte, C.; Smith, J.R.; Tan, C.T.; Krakoff, I.H. Bleomycin, an antitumor antibiotic. Clinical experience in 274 patients. Ann. Intern. Med. 1972, 77, 861-870. [CrossRef]

122. Muggia, F.M.; Louie, A.C.; Sikic, B.I. Pulmonary toxicity of antitumor agents. Cancer Treat. Rev. 1983, 10, 221-243. [CrossRef]

123. Janick-Buckner, D.; Ranges, G.E.; Hacker, M.P. Alteration of bronchoalveolar lavage cell populations following bleomycin treatment in mice. Toxicol. Appl. Pharmacol. 1989, 100, 465-473. [CrossRef]

124. Schrier, D.J.; Kunkel, R.G.; Phan, S.H. The role of strain variation in murine bleomycin-lnduced pulmonary fibrosis. Am. Rev. Respir. Dis. 1983, 127, 63-66. [CrossRef] [PubMed]

125. Pitozzi, V.; Caruso, P.; Bonatti, M.; Bignami, F.; Pittelli, M.G.; Pontis, S.; Frati, C.; Mangiaracina, C.; Quaini, F.; Lagrasta, C.; et al. Time-course analysis of bleomycin-induced lung fibrosis in the rat. Eur. Respir. J. 2018, 52, PA1001.

126. Kolb, P.; Upagupta, C.; Vierhout, M.; Ayaub, E.; Bellaye, P.S.; Gauldie, J.; Shimbori, C.; Inman, M.; Ask, K.; Kolb, M.R.J. The importance of interventional timing in the bleomycin model of pulmonary fibrosis. Eur. Respir. J. 2020, 55, 1901105. [CrossRef]

127. Roberts, S.; Howie, S.; Wallace, W.; Brown, D.; Lamb, D.; Ramage, E.; Donaldson, K. A novel model for human interstitial lung disease: Hapten-driven lung fibrosis in rodents. J. Pathol. 1995, 176, 309-318. [CrossRef]

128. Christensen, P.J.; Goodman, R.E.; Pastoriza, L.; Moore, B.; Toews, G.B. Induction of lung fibrosis in the mouse by intratracheal instillation of fluorescein isothiocyanate is not t-cell-dependent. Am. J. Pathol. 1999, 155, 1773-1779. [CrossRef]

129. Oberdorster, G. Significance of particle parameters in the evaluation of exposure-dose-response relationships of inhaled particles. Inhal. Toxicol. 1996, 8, 73-89. [CrossRef]

130. Lardot, C.G.; Huaux, F.O.A.; Broeckaert, F.R.; Declerck, P.J.; Delos, M.; Fubini, B.; LISON, D.F. Role of urokinase in the fibrogenic response of the lung to mineral particles. Am. J. Respir. Crit. Care Med. 1998, 157, 617-628. [CrossRef]

131. Lakatos, H.F.; Burgess, H.A.; Thatcher, T.H.; Redonnet, M.R.; Hernady, E.; Williams, J.P.; Sime, P.J. Oropharyngeal aspiration of a silica suspension produces a superior model of silicosis in the mouse when compared to intratracheal instillation. Exp. Lung Res. 2006, 32, 181-199. [CrossRef]

132. D'Armiento, J.; Dalal, S.S.; Okada, Y.; Berg, R.A.; Chada, K. Collagenase expression in the lungs of transgenic mice causes pulmonary emphysema. Cell 1992, 71, 955-961. [CrossRef]

133. Korfhagen, T.R.; Swantz, R.J.; Wert, S.E.; McCarty, J.M.; Kerlakian, C.B.; Glasser, S.W.; Whitsett, J.A. Respiratory epithelial cell expression of human transforming growth factor-alpha induces lung fibrosis in transgenic mice. J. Clin. Investig. 1994, 93, 1691-1699. [CrossRef] [PubMed]

134. Tang, W.; Geba, G.P.; Zheng, T.; Ray, P.; Homer, R.J.; Kuhn, C.; Flavell, R.A.; Elias, J.A. Targeted expression of il-11 in the murine airway causes lymphocytic inflammation, bronchial remodeling, and airways obstruction. J. Clin. Investig. 1996, 98, 2845-2853. [CrossRef]

135. Xing, Z.; Braciak, T.; Ohkawar, Y.; Sallenave, J.M.; Foley, R.; Sime, P.J.; Jordana, M.; Graham, F.L.; Gauldie, J. Gene transfer for cytokine functional studies in the lung: The multifunctional role of gm-csf in pulmonary inflammation. J. Leukoc. Biol. 1996, 59, 481-488. [CrossRef]

136. Miyazaki, Y.; Araki, K.; Vesin, C.; Garcia, I.; Kapanci, Y.; Whitsett, J.; Piguet, P.; Vassalli, P. Expression of a tumor necrosis factor-alpha transgene in murine lung causes lymphocytic and fibrosing alveolitis. A mouse model of progressive pulmonary fibrosis. J. Clin. Investig. 1995, 96, 250-259. [CrossRef]

137. Sime, P.J.; Xing, Z.; Graham, F.L.; Csaky, K.G.; Gauldie, J. Adenovector-mediated gene transfer of active transforming growth factor-beta1 induces prolonged severe fibrosis in rat lung. J. Clin. Investig. 1997, 100, 768-776. [CrossRef] [PubMed]

138. Kolb, M.; Margetts, P.J.; Anthony, D.C.; Pitossi, F.; Gauldie, J. Transient expression of il-1 $\beta$ induces acute lung injury and chronic repair leading to pulmonary fibrosis. J. Clin. Investig. 2001, 107, 1529-1536. [CrossRef]

139. Engelhardt, J.F.; Litzky, L.; Wilson, J.M. Prolonged transgene expression in cotton rat lung with recombinant adenoviruses defective in e2a. Hum. Gene Ther. 1994, 5, 1217-1229. [CrossRef]

140. Silvertown, J.D.; Walia, J.S.; Summerlee, A.J.; Medin, J.A. Functional expression of mouse relaxin and mouse relaxin-3 in the lung from an ebola virus glycoprotein-pseudotyped lentivirus via tracheal delivery. Endocrinology 2006, 147, 3797-3808. [CrossRef]

141. Bonfield, T.L.; Koloze, M.; Lennon, D.P.; Zuchowski, B.; Yang, S.E.; Caplan, A.I. Human mesenchymal stem cells suppress chronic airway inflammation in the murine ovalbumin asthma model. Am. J. Physiol. Lung Cell. Mol. Physiol. 2010, 299, L760-L770. [CrossRef] [PubMed] 
142. Fang, X.H.; Abbott, J.; Cheng, L.D.; Colby, J.K.; Lee, J.W.; Levy, B.D.; Matthay, M.A. Human mesenchymal stem (stromal) cells promote the resolution of acute lung injury in part through lipoxin a4. J. Immunol. 2015, 195, 875-881. [CrossRef]

143. Jun, D.; Garat, C.; West, J.; Thorn, N.; Chow, K.; Cleaver, T.; Sullivan, T.; Torchia, E.C.; Childs, C.; Shade, T.; et al. The pathology of bleomycin-induced fibrosis is associated with loss of resident lung mesenchymal stem cells that regulate effector $\mathrm{t}$-cell proliferation. Stem Cells 2011, 29, 725-735. [CrossRef]

144. Mei, S.H.J.; Haitsma, J.J.; Dos Santos, C.C.; Deng, Y.P.; Lai, P.F.H.; Slutsky, A.S.; Liles, W.C.; Stewart, D.J. Mesenchymal stem cells reduce inflammation while enhancing bacterial clearance and improving survival in sepsis. Am. J. Respir. Crit. Care Med. 2010, 182, 1047-1057. [CrossRef]

145. Balogh, E.; Nagy, B., Jr.; Gyetvai, A.; Bene, Z.; Hendrik, Z.; Jeney, V.; Nagy, P.; Papp, A.; Balla, J.; Balla, G.; et al. Impaired immunosuppressive effect of bronchoalveolar mesenchymal stem cells in hypersensitivity pneumonitis: Preliminary findings. Cytom. Part B Clin. Cytom. 2018, 94, 363-368. [CrossRef] [PubMed]

146. Geiger, S.; Hirsch, D.; Hermann, F.G. Cell therapy for lung disease. Eur. Respir. Rev. 2017, 26, 170044. [CrossRef]

147. Chen, S.; Cui, G.; Peng, C.; Lavin, M.F.; Sun, X.; Zhang, E.; Yang, Y.; Guan, Y.; Du, Z.; Shao, H. Transplantation of adipose-derived mesenchymal stem cells attenuates pulmonary fibrosis of silicosis via anti-inflammatory and anti-apoptosis effects in rats. Stem Cell Res. Ther. 2018, 9, 110. [CrossRef]

148. Cores, J.; Hensley, M.T.; Kinlaw, K.; Rikard, S.M.; Dinh, P.U.; Paudel, D.; Tang, J.; Vandergriff, A.C.; Allen, T.A.; Li, Y.; et al. Safety and efficacy of allogeneic lung spheroid cells in a mismatched rat model of pulmonary fibrosis. Stem Cells Transl. Med. 2017, 6, 1905-1916. [CrossRef] [PubMed]

149. Liu, L.; Mao, Q.; Chu, S.; Mounayar, M.; Abdi, R.; Fodor, W.; Padbury, J.F.; De Paepe, M.E. Intranasal versus intraperitoneal delivery of human umbilical cord tissue-derived cultured mesenchymal stromal cells in a murine model of neonatal lung injury. Am. J. Pathol. 2014, 184, 3344-3358. [CrossRef]

150. Mansouri, N.; Willis, G.R.; Fernandez-Gonzalez, A.; Reis, M.; Nassiri, S.; Mitsialis, S.A.; Kourembanas, S. Mesenchymal stromal cell exosomes prevent and revert experimental pulmonary fibrosis through modulation of monocyte phenotypes. JCI Insight 2019, 4, 4. [CrossRef] [PubMed]

151. Thebaud, B.; Abman, S.H. Bronchopulmonary dysplasia-Where have all the vessels gone? Roles of angiogenic growth factors in chronic lung disease. Am. J. Respir. Crit. Care Med. 2007, 175, 978-985. [CrossRef]

152. Moreira, A.; Winter, C.; Joy, J.; Winter, L.; Jones, M.; Noronha, M.; Porter, M.; Quim, K.; Corral, A.; Alayli, Y.; et al. Intranasal delivery of human umbilical cord wharton's jelly mesenchymal stromal cells restores lung alveolarization and vascularization in experimental bronchopulmonary dysplasia. Stem Cells Transl. Med. 2020, 9, 221-234. [CrossRef]

153. Porzionato, A.; Zaramella, P.; Dedja, A.; Guidolin, D.; Bonadies, L.; Macchi, V.; Pozzobon, M.; Jurga, M.; Perilongo, G.; De Caro, R.; et al. Intratracheal administration of mesenchymal stem cell-derived extracellular vesicles reduces lung injuries in a chronic rat model of bronchopulmonary dysplasia. Am. J. Physiol. Lung Cell. Mol. Physiol. 2021, 320, L688-L704. [CrossRef]

154. Aslam, M.; Baveja, R.; Liang, O.D.; Fernandez-Gonzalez, A.; Lee, C.; Mitsialis, S.A.; Kourembanas, S. Bone marrow stromal cells attenuate lung injury in a murine model of neonatal chronic lung disease. Am. J. Respir. Crit. Care Med. 2009, 180, 1122-1130. [CrossRef]

155. Hansmann, G.; Fernandez-Gonzalez, A.; Aslam, M.; Vitali, S.H.; Martin, T.; Mitsialis, S.A.; Kourembanas, S. Mesenchymal stem cell-mediated reversal of bronchopulmonary dysplasia and associated pulmonary hypertension. Pulm. Circ. 2012, 2, 170-181. [CrossRef]

156. Zhu, Y.; Chen, X.; Yang, X.; El-Hashash, A. Stem cells in lung repair and regeneration: Current applications and future promise. J. Cell. Physiol. 2018, 233, 6414-6424. [CrossRef] [PubMed]

157. Laffey, J.G.; Matthay, M.A. Fifty years of research in ards. Cell-based therapy for acute respiratory distress syndrome. Biology and potential therapeutic value. Am. J. Respir. Crit. Care Med. 2017, 196, 266-273. [CrossRef] [PubMed]

158. O'Reilly, M.; Thebaud, B. Cell-based therapies for neonatal lung disease. Cell Tissue Res. 2017, 367, 737-745. [CrossRef]

159. Kokturk, N.; Yildirim, F.; Gulhan, P.Y.; Oh, Y.M. Stem cell therapy in chronic obstructive pulmonary disease. How far is it to the clinic? Am. J. Stem Cells 2018, 7, 56-71. [PubMed]

160. Chang, Y.S.; Ahn, S.Y.; Yoo, H.S.; Sung, S.I.; Choi, S.J.; Oh, W.I.; Park, W.S. Mesenchymal stem cells for bronchopulmonary dysplasia: Phase 1 dose-escalation clinical trial. J. Pediatr. 2014, 164, 966-972.e966. [CrossRef]

161. Ahn, S.Y.; Chang, Y.S.; Kim, J.H.; Sung, S.I.; Park, W.S. Two-year follow-up outcomes of premature infants enrolled in the phase i trial of mesenchymal stem cells transplantation for bronchopulmonary dysplasia. J. Pediatr. 2017, 185, 49-54.e42. [CrossRef]

162. Ahn, S.Y.; Chang, Y.S.; Lee, M.H.; Sung, S.I.; Lee, B.S.; Kim, K.S.; Kim, A.R.; Park, W.S. Stem cells for bronchopulmonary dysplasia in preterm infants: A randomized controlled phase ii trial. Stem Cells Transl. Med. 2021, 10, 1129-1137. [CrossRef]

163. Powell, S.B.; Silvestri, J.M. Safety of intratracheal administration of human umbilical cord blood derived mesenchymal stromal cells in extremely low birth weight preterm infants. J. Pediatr. 2019, 210, 209-213.e202. [CrossRef] [PubMed]

164. Calcaterra, V.; Avanzini, M.A.; Mantelli, M.; Agolini, E.; Croce, S.; De Silvestri, A.; Re, G.; Collura, M.; Maltese, A.; Novelli, A.; et al. A case report on filamin a gene mutation and progressive pulmonary disease in an infant: A lung tissued derived mesenchymal stem cell study. Medicine 2018, 97, e13033. [CrossRef] [PubMed]

165. Sasaki, E.; Byrne, A.T.; Phelan, E.; Cox, D.W.; Reardon, W. A review of filamin a mutations and associated interstitial lung disease. Eur. J. Pediatr. 2019, 178, 121-129. [CrossRef] [PubMed] 